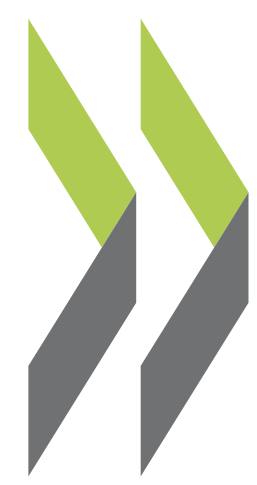

OECD Local Economic and Employment Development (LEED) Papers 2018/01

\title{
The role of technical and vocational education and training (TVET)
} in fostering inclusive growth at the local level in Southeast Asia

\section{OECD}




\section{The role of technical and vocational education and training (TVET) in fostering inclusive growth at the local level in Southeast Asia}

The purpose of this paper is to explore the potential of technical and vocational education and training (TVET) for fostering inclusive growth at the local level in the Association of Southeast Asian Nations (ASEAN) region. The first section provides a brief overview of the main developmental challenges in the ASEAN region that have resulted in growing inequalities in wealth distribution. The second and third sections review evidence from developed as well as developing countries regarding TVET's impact on employment and wages (Section 2), as well as on poverty, inequality and social exclusion (Section 3). Section 4 summarises the key findings and highlights lessons learned for the ASEAN region. Good practice examples from the region are presented to illustrate how countries have used TVET to improve economic and social outcomes at the local level.

JEL classification: I25, J24, J46

Keywords: training, skills, local 
OECD Working Papers should not be reported as representing the official views of the OECD or of its member countries. The opinions expressed and arguments employed are those of the author(s).

This document, as well as any [statistical] data and map included herein, are without prejudice to the status of or sovereignty over any territory, to the delimitation of international frontiers and boundaries and to the name of any territory, city or area.

Working Papers describe preliminary results or research in progress by the author(s) and are published to stimulate discussion on a broad range of issues on which the OECD works. Comments on Working Papers are welcome, and may be sent to the Centre for Entrepreneurship, SMEs, Regions and Cities, OECD, 2 rue André-Pascal, 75775 Paris Cedex 16, France.

Authorised for publication by Lamia Kamal-Chaoui, Director, Centre for Entrepreneurship, SMEs, Regions and Cities, OECD.

OECD Local Economic and Employment Development (LEED) Working Papers are published on: https://doi.org/10.1787/20794797.

\section{(C) OECD 2018}

You can copy, download or print OECD content for your own use, and you can include excerpts from OECD publications, databases and multimedia products in your own documents, presentations, blogs, websites and teaching materials, provided that suitable acknowledgment of OECD as source and copyright owner is given. All requests for commercial use and translation rights should be submitted to rights@oecd.org. 


\section{Table of contents}

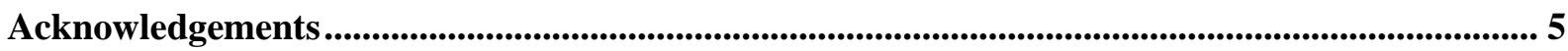

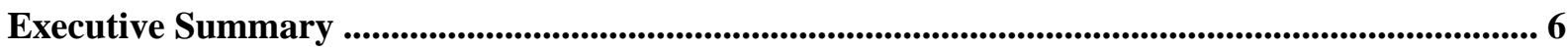

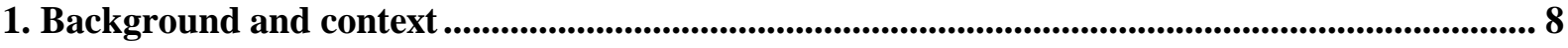

2. TVET's relative impact (versus general education) on employment and wages ........................ 15

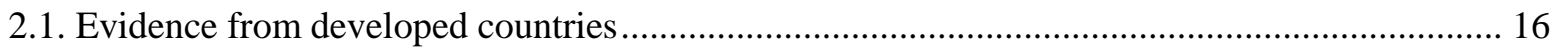

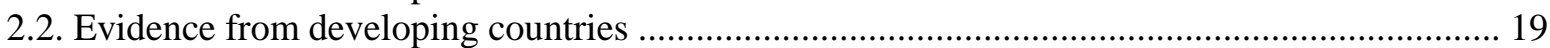

2.3. Comparison between developed and developing countries' experiences .................................. 22

2.4. Key takeaways for closing the gap between developed and developing countries..................... 23

3. TVET's impact on poverty, inequality and social exclusion ............................................................ 24

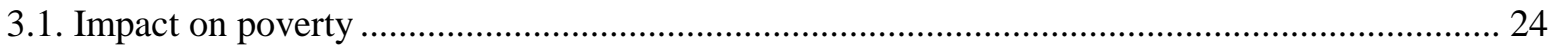

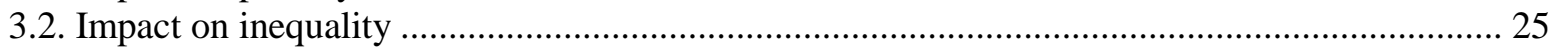

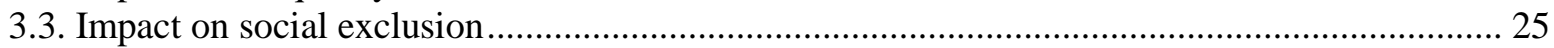

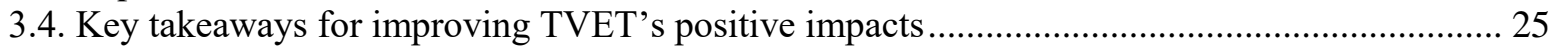

4. Unleashing TVET's potential for fostering inclusive growth at the local level in the ASEAN region: key findings and good practice examples

4.1. Key findings on TVET's role in fostering inclusive growth at the local level in the ASEAN

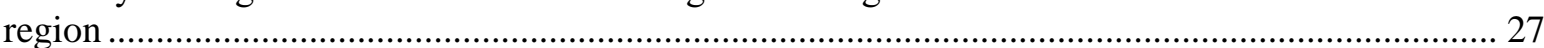

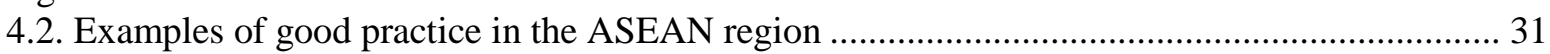

5. Conclusion and recommendations for further research and analysis ........................................... 34

References ….................................................................................................................................................................... 35

Tables

Table 4.1. Examples of good practice from the ASEAN region for harnessing TVET's potential for

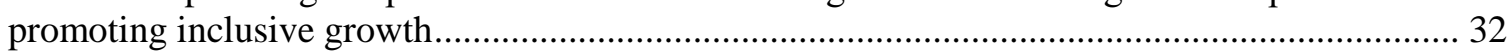

Figures

Figure 1.1. Change in GDP, PPP (Constant 2011 international \$), ASEAN countries and OECD

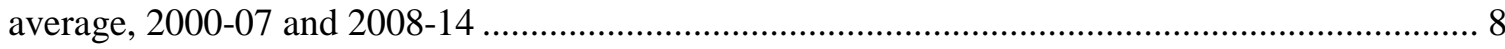

Figure 1.2. Poverty headcount ratio at $\$ 1.90$ a day (2011 PPP) (\% of population), 1993-2012 _........... 8

Figure 1.3. Wealth disparity between ASEAN countries by income group, 1993-2016 ....................... 9

Figure 1.4. Income inequality levels across developing regions ........................................................ 10

Figure 1.5. Wealth disparity within ASEAN countries by income group, 1990s to 2000s .................. 10

Figure 1.6. Unemployment rate, total population (\% of total labour force) and youth population

(15-24), ASEAN countries and OECD average, 2017

Figure 1.7. The share of own account and contributing family workers (as a percentage of total employment) in ASEAN region 2012/13 
Figure 1.8. Labour force participation by gender in ASEAN countries, 2017 ................................... 13

Figure 1.9. Women's percentage share of senior and middle management positions in ASEAN countries, latest available data

Figure 4.1. TVET enrolments as a percentage of gross upper secondary enrolments, by sex, in 201528

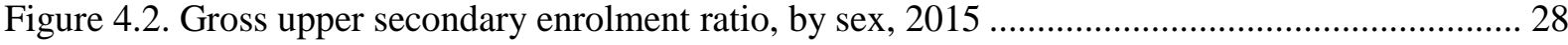

Figure 4.3. Access to TVET in Vietnam, by location and sex, SY2007 ............................................ 29

Figure 4.4. Employers' perceptions of education/training relevance, by track and level ..................... 30

Figure 4.5. Employers' level of agreement that TVET matches their skills needs ............................... 31 


\section{Acknowledgements}

This working paper has been prepared by the Local Employment, Skills and Social Innovation (LESI) Division as part of the OECD Local Economic and Employment Development (LEED) Programme under the leadership of Sylvain Giguère, Head of Division, within the Centre for Entrepreneurship, SMEs, Regions and Cities, overseen by Lamia Kamal-Chaoui, Director.

The paper has been prepared within the framework of the OECD Southeast Asia Regional Network on Education/Employment and Skills Strategies Initiative in Southeast Asia (ESSSA), which is co-ordinated by Jonathan Barr, Head of the Employment and Skills Unit within the LESI Division.

This working paper was prepared by Gita Subrahmanyam, Research Associate at the London School of Economics, supervised by and with input from Jonathan Barr (Head of Unit) and Anna Choi (Policy Analyst). Valuable feedback on the paper was provided on the paper by Anthony Mann of the OECD's Directorate of Education (EDU).

Special thanks should be given to the Foreign and Commonwealth Office (FCO) of the United Kingdom who support the development of this paper. However, the contents of the report, including the opinions expressed herein, are the responsibility of the OECD and should not be attributed to the FCO. 


\section{Executive Summary}

Despite impressive economic growth and reductions in poverty over the past two decades, countries within the Association of Southeast Asian Nations (ASEAN) region continue to struggle with inequality, since increased wealth in the region has not been fairly distributed across all segments of society. While trends in inequality vary across countries in the region, women and young people tend to be the most disadvantaged, with higher unemployment and informal employment rates than other groups, resulting in higher levels of economic disengagement and social marginalisation. Inequality matters, not only in its own right, but also because it can hamper growth and decrease the poverty reduction impact of growth. Conversely, the foundations for future growth and poverty reduction can be strengthened if the benefits of development are shared broadly and equitably across populations.

The review of international evidence presented in this paper suggests that technical and vocational education and training (TVET) could be a powerful tool for addressing multiple developmental challenges and fostering inclusive growth at the local level in the ASEAN region. The findings of this paper show:

- that well-designed formal TVET programmes may be more effective than general (or academic) education for integrating marginalised groups (such as women and youth) into the labour market and improving their earnings; and

- that informal and non-formal TVET initiatives can play a role in reducing poverty, inequality and social exclusion by offering disadvantaged and marginalised groups the opportunity to acquire work-relevant skills.

However, TVET has not had a significant positive impact on the economic outcomes and social well-being of disadvantaged and marginalised groups in the ASEAN region for several reasons. These include low TVET participation rates, primarily due to low public spending on TVET; poor TVET quality, especially in countries with low national income; and weak TVET relevance, owing to lack of engagement of key stakeholders, especially the private sector, in local TVET planning, design and implementation. Yet, despite these issues, recent evidence suggests that TVET is valued and well-regarded by employers in the region and that many ASEAN countries have harnessed TVET's potential to promote economic and social inclusion. Good practice examples from the region are presented in the report.

Further research and analysis are required to deepen and extend the findings of the paper. Suggested areas for future research and analysis include:

- Analysis of the potential costs and benefits of proposed solutions to challenges in the TVET sector - for example, the potential negative and positive implications of new technology on skills and jobs in the future;

- Collection of further good practice examples showing how countries, regions and cities have used TVET to improve local economic and social outcomes;

- Exploration of the potential for, as well as challenges inherent in, adapting and transferring good practices across countries in the region, especially from the wealthiest to the poorest CLMV (Cambodia, Lao PDR, Myanmar and Vietnam, or CLMV) countries; 
- Further analysis of TVET institutional arrangements within the ASEAN region to identify system design and funding policy principles to improve the quality and access of local programmes;

- A mapping of donor activities in the TVET sector, across and within countries in the region to understand the role of the NGO sector in expanding TVET quality. 


\section{Background and context}

Over the past two decades, ASEAN countries have experienced rapid economic growth (see Figure 1.1), averaging around 5.3\% per year from 2000 to 2013 (ASEAN Secretariat, 2015), and high productivity gains, as the region's largely agrarian societies have been transformed into dynamic, export-oriented economies. Increased labour productivity in sectors such as manufacturing, retail, telecommunications, and transportation explains around $60 \%$ of total growth in the ASEAN region since 1990 (McKinsey \& Company, 2014). Fast growth combined with market-friendly reforms has allowed countries in the region to lift millions of individuals out of poverty (see Figure 1.2).

Figure 1.1. Change in GDP, PPP (Constant 2011 international \$), ASEAN countries and OECD average, 2000-07 and 2008-14

Average annual change (\%)

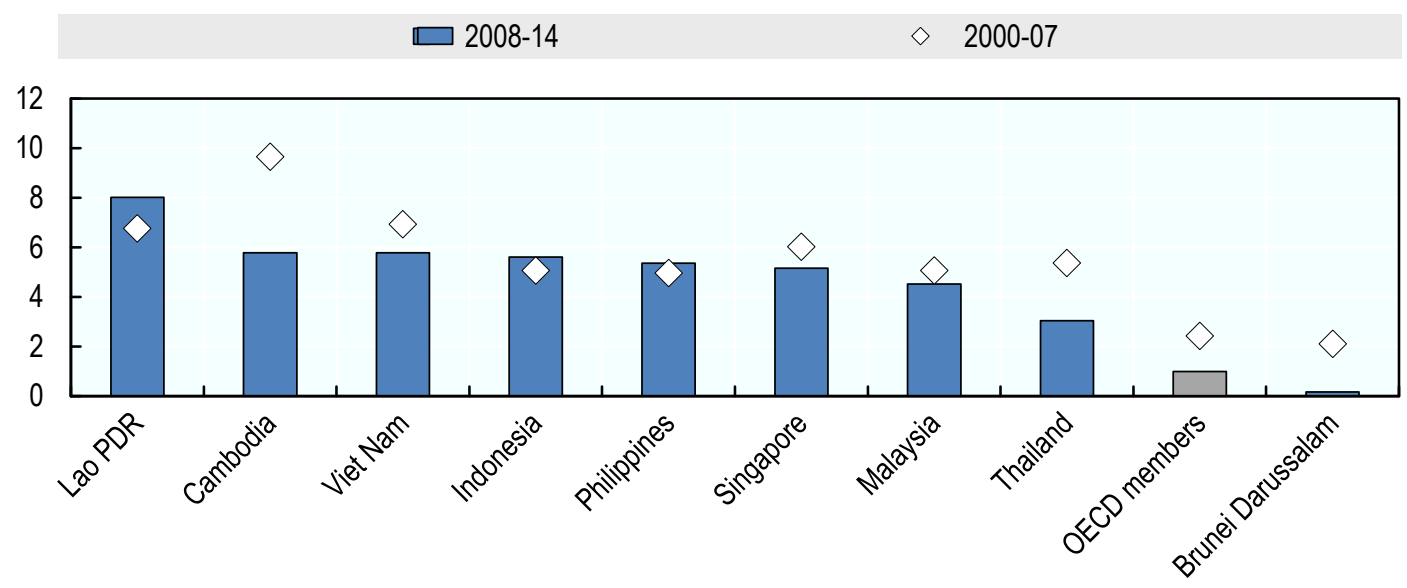

Source: OECD/ADB, 2017; World Bank, International Comparison Program database.

Figure 1.2. Poverty headcount ratio at $\$ 1.90$ a day (2011 PPP) (\% of population), 1993-2012

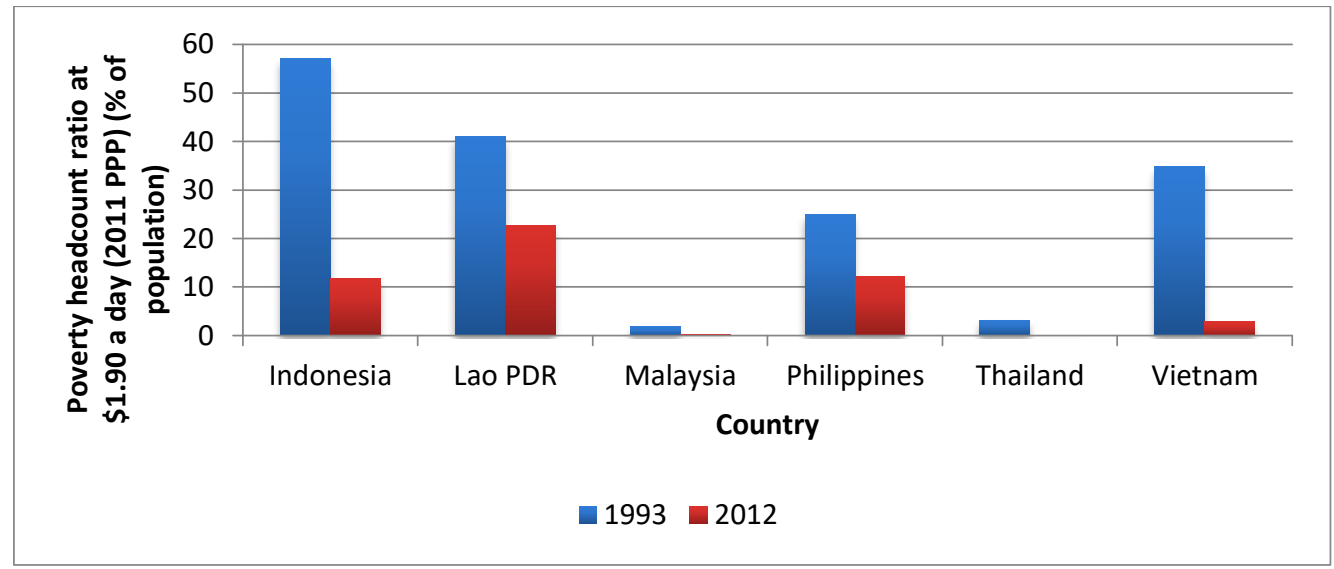

Source: World Bank, World Development Indicators database (accessed 3 March 2018). 
Because the region's poorer economies have grown at a faster rate than the wealthier economies, income inequalities between countries in the region have narrowed. This can be seen by dividing the ten ASEAN countries into three groups - wealthiest (Brunei Darussalam, Singapore and Malaysia), middle (Thailand, Indonesia, the Philippines), and poorest (Cambodia, Lao PDR, Myanmar and Vietnam, or CLMV) - and calculating the wealth disparity, defined as the ratio of 'wealthiest' to 'poorest' (CLMV) countries in GDP per capita terms (see Figure 1.3). The trends displayed in Figure 1.3 show that the wealth disparity between countries in the ASEAN region has decreased since 1990, falling from 35 in 1993 to 10 in 2016. While the reduction in the ratio is partly a mathematical phenomenon - after all, a doubling of GDP is more easily achieved at lower GDP levels than at higher GDP levels - the trends nevertheless suggest that the poorer CLMV countries are 'catching up' to the wealthier countries.

Figure 1.3. Wealth disparity between ASEAN countries by income group, 1993-2016

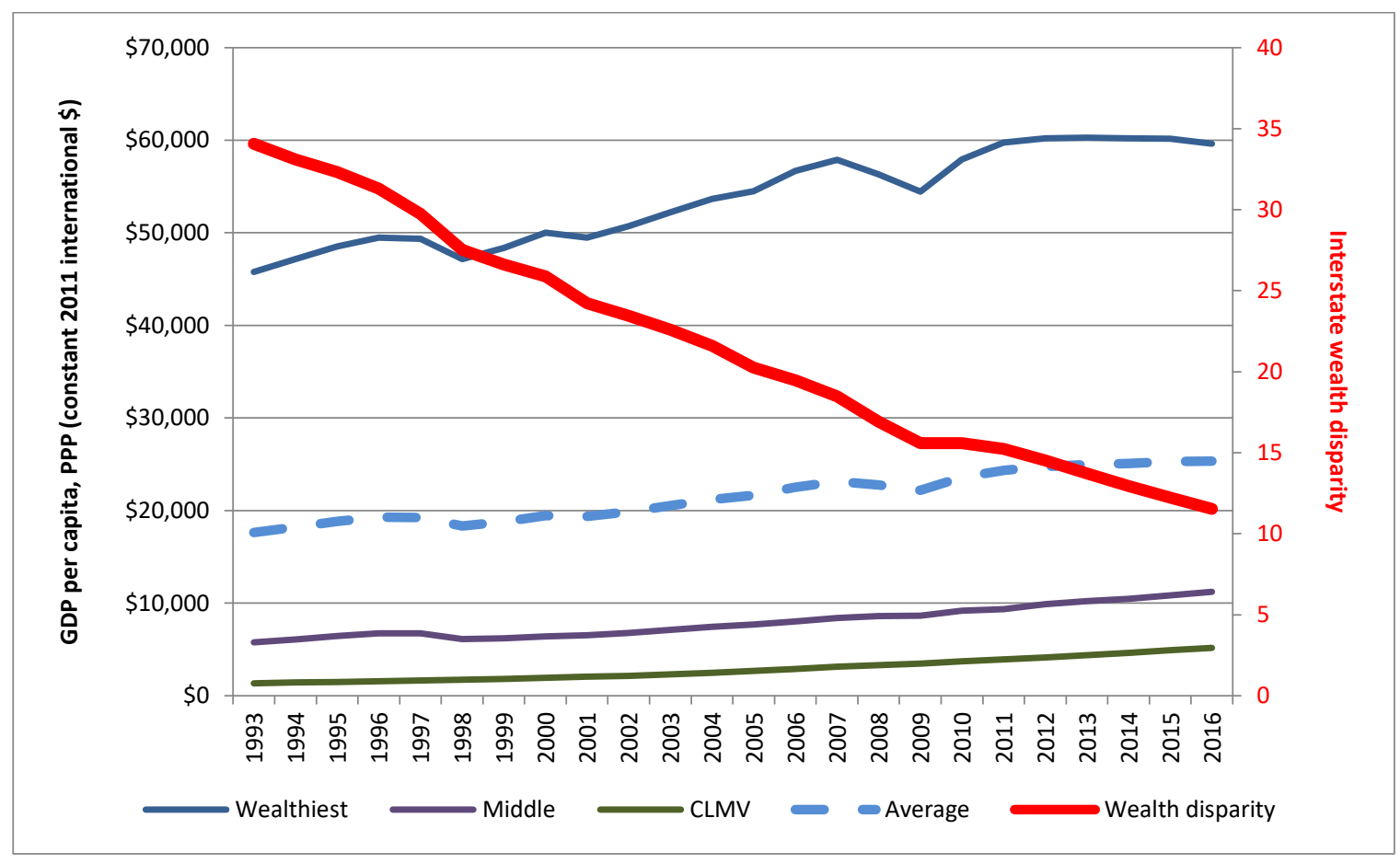

Source: World Bank (2018), World Development Indicators database (accessed 3 March 2018).

Yet, despite impressive economic growth and success in poverty reduction across the region, income inequality within ASEAN countries continues to pose a challenge. Comparing trends across world regions shows that income inequality - as measured by the Gini coefficient ${ }^{1}$ - is much higher among the ASEAN-5 countries (Indonesia, Malaysia, the Philippines, Singapore, and Thailand) than among OECD and other advanced economies (see Figure 1.4). Moreover, within-country wealth disparities have risen across the ASEAN region, with the wealthiest countries tending to have the highest Gini coefficients, while the poorest (CLMV) countries exhibit the fastest growth

\footnotetext{
${ }^{1}$ The Gini coefficient (or index) is a commonly-used measure of income inequality that condenses a country's income distribution into a single number. The coefficient varies between 0 , which reflects complete equality, and 1, which indicates complete inequality. The Gini coefficient is often reported as a whole number (e.g., 35) rather than a ratio (e.g. 0.35).
} 
in inequality (see Figure 1.5). However, trends in inequality vary across individual countries. For example, Indonesia has experienced the greatest increase in wealth disparity since 1990, and Singapore has also become more unequal (IMF, 2016). Conversely, Thailand, Malaysia and the Philippines have been able to reduce income inequality, partly through targeted government policies.

Figure 1.4. Income inequality levels across developing regions

(Net Gini Index; in Gini points; 2013; average across the region)

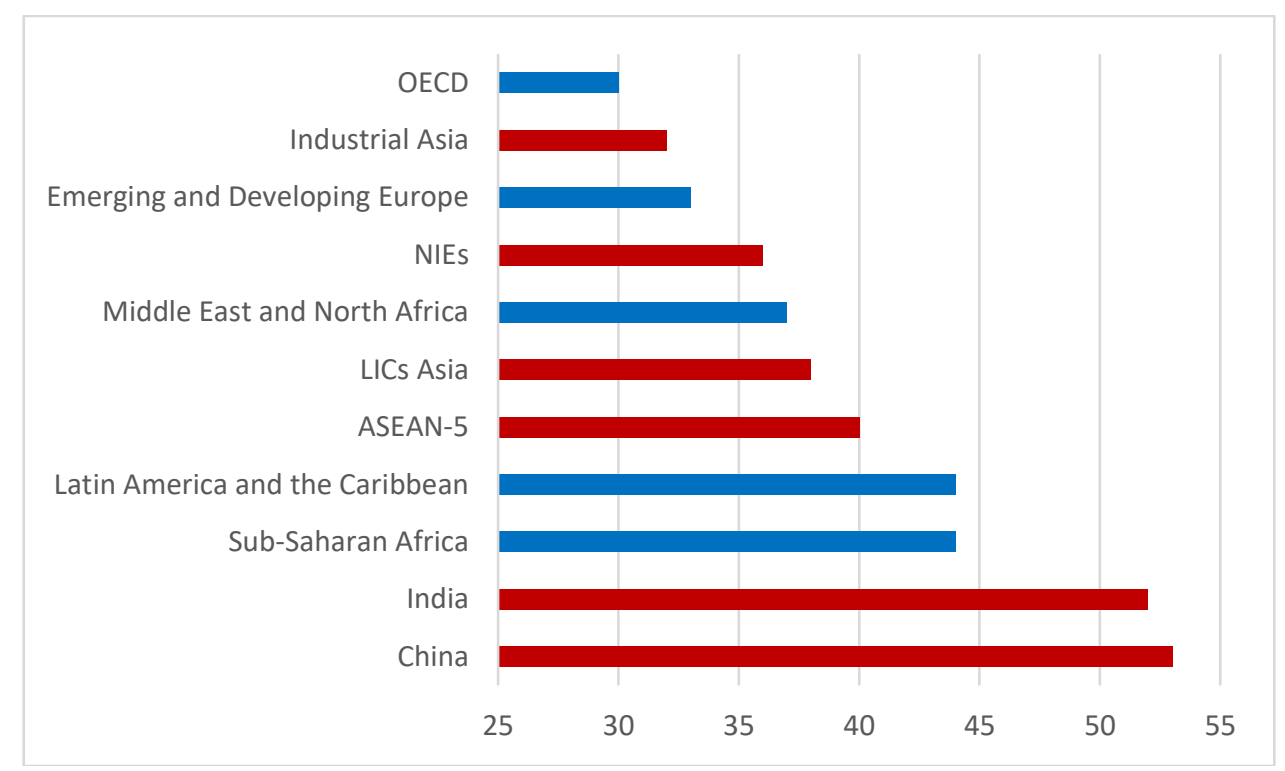

Note: ASEAN-5 = Indonesia, Malaysia, the Philippines, Singapore, and Thailand; LIC = low-income countries; NIEs $=$ newly industrialized economies

Source: IMF (2016). SWIID Version 5.0; IMF, World Economic Outlook database; and IMF staff calculations.

Figure 1.5. Wealth disparity within ASEAN countries by income group, 1990s to 2000s

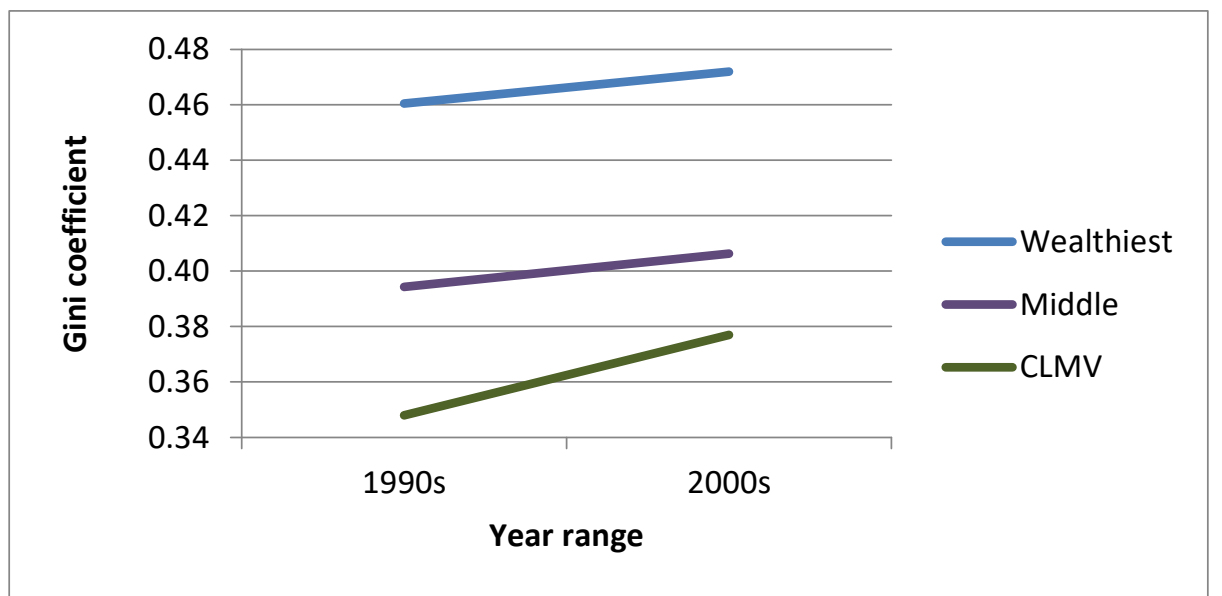

Source: ADB (2014a) Inequality in Asia and the Pacific: trends, drivers and policy implications (Manila: ADB), pp. 24-25.

Nevertheless, in every country in the region, some groups have received fewer dividends from increased prosperity than others. Women tend to earn lower wages than men in every 
ASEAN country for which data is available, apart from the Philippines, with Cambodia and Singapore exhibiting the greatest gender wage gaps (ASEAN Secretariat, 2016). Young workers are more likely to be unemployed than older workers, but are especially disadvantaged in Brunei Darussalam and Indonesia (see Figure 1.6). Which groups benefit least from wealth distribution sometimes differs across countries in the region: for example, income inequality has grown faster in urban areas than in rural areas of Indonesia, while the opposite is true in the Philippines (Kanbur and Zhuang, 2013).

Figure 1.6. Unemployment rate, total population (\% of total labour force) and youth population (15-24), ASEAN countries and OECD average, 2017

Total and youth unemployment rate

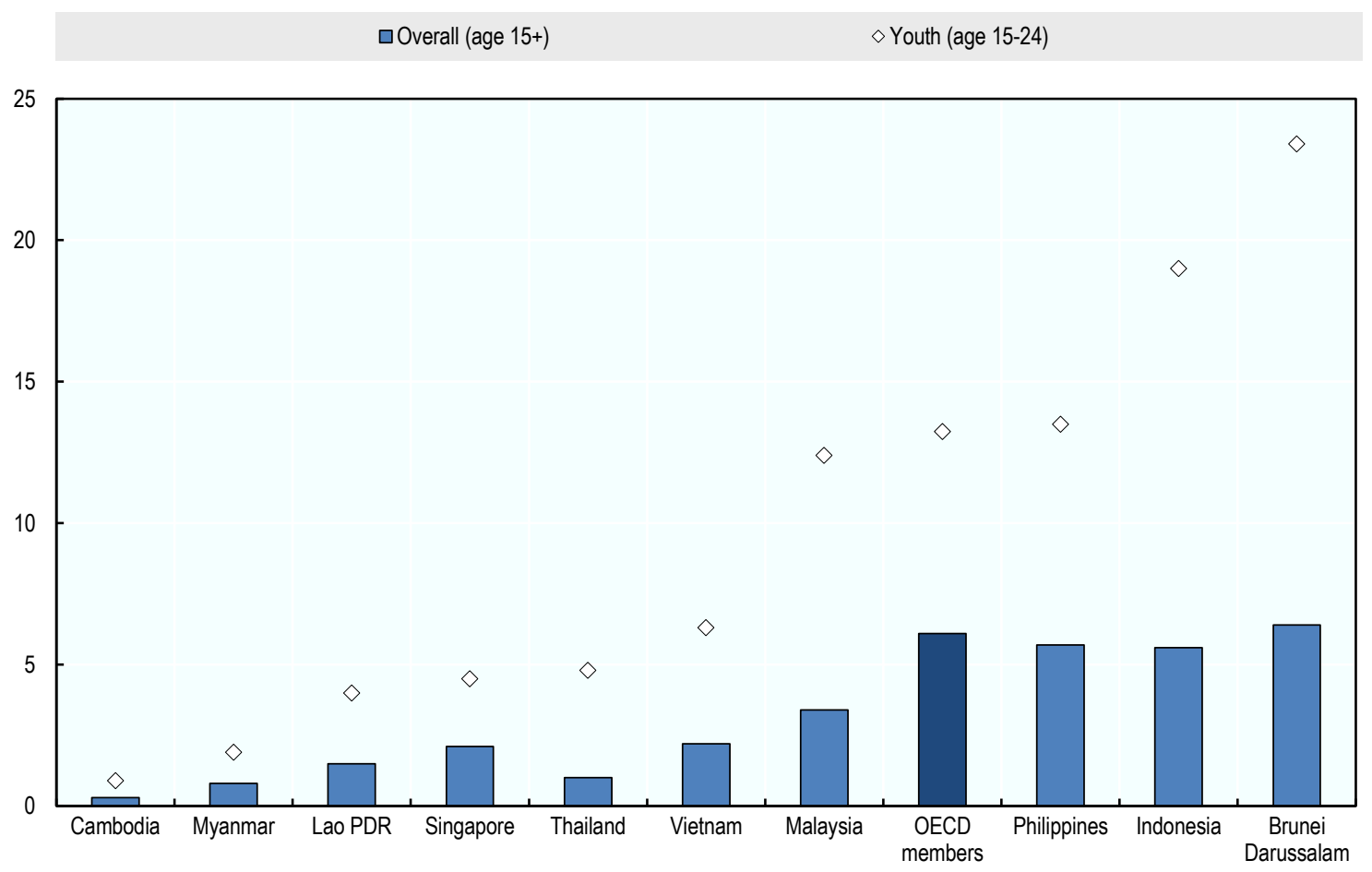

Source: World Bank, World Development Indicators database (accessed 3 March 2018).

Income inequalities in the ASEAN region are not so much a consequence of high unemployment as of poor job quality. After all, every country in the region, apart from Brunei Darussalam, had a lower unemployment rate than the OECD average of $6.1 \%$ in 2017 (see Figure 1.6). However, a large share of workers in the region -in particular, young workers and female workers - are employed in informal or vulnerable, rather than decent, jobs. ${ }^{2}$ In some ASEAN countries, informality is very high: for example, vulnerable employment, which encompasses own-account and contributing family workers, accounted for over 80\% of total employment in Lao PDR in 2010 and exceeded 50\% in Cambodia,

\footnotetext{
2 The International Labour Organisation defines 'decent work' as 'opportunities for work that are productive and deliver a fair income, security in the workplace and social protection for families, better prospects for personal development and social integration, freedom for people to express their concerns, organize and participate in the decisions that affect their lives and equality of opportunity and treatment for all women and men' (ILO, n.d.).
} 
Indonesia, Thailand and Vietnam in 2012/13 (see Figure 1.7). Because informal employment tends to be correlated with low earnings, many informal workers become trapped in poverty. In 2014, 30.3\% of workers in the ASEAN region earned less than $\$ 2$ per day, compared with $26.7 \%$ of all workers globally (ILO and ADB, 2014). Women are more susceptible to vulnerable employment than men in seven of the nine ASEAN countries for which there is data (ILO and ADB, 2014).

Figure 1.7. The share of own account and contributing family workers (as a percentage of total employment) in ASEAN region 2012/13

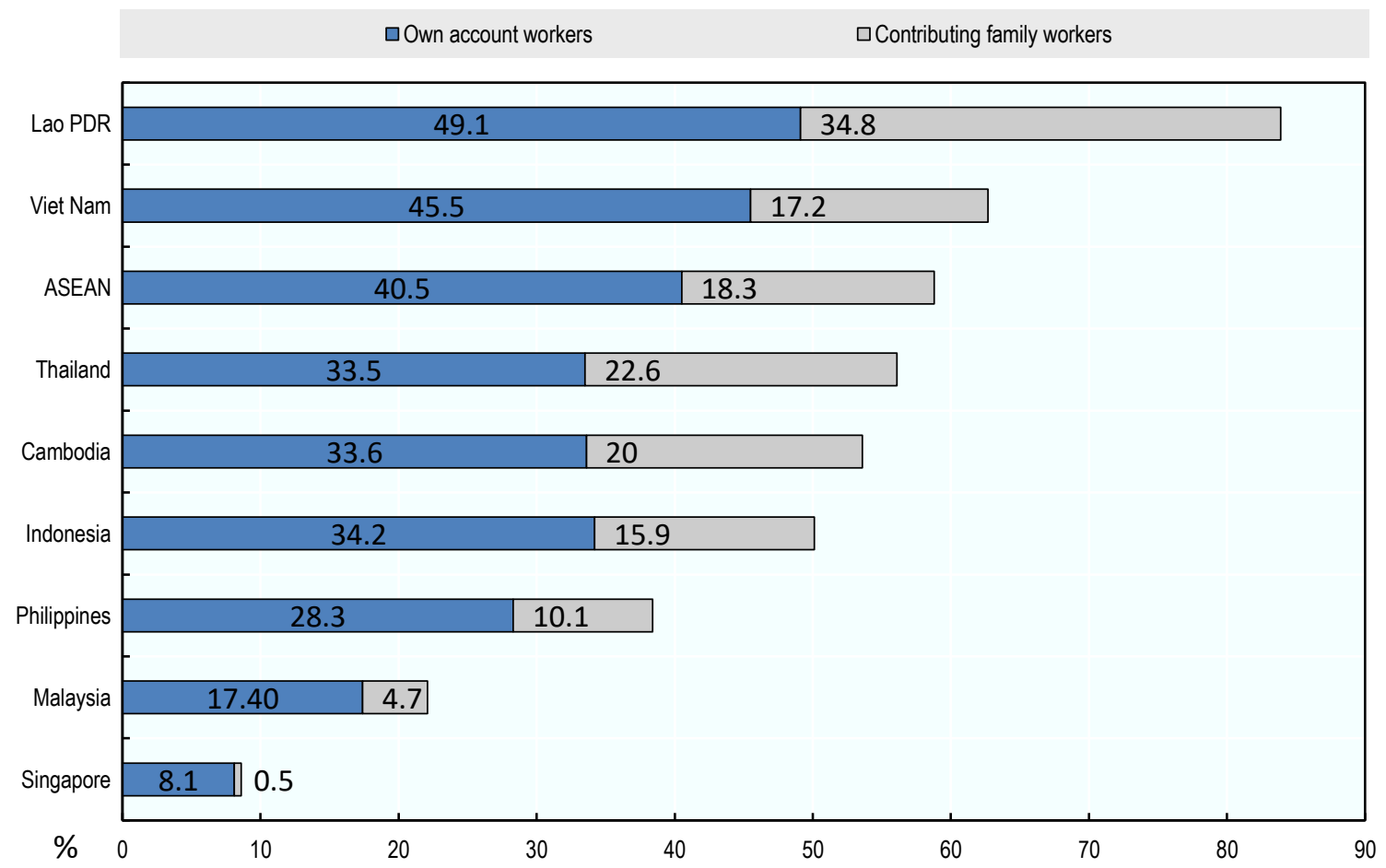

Source: Official national sources; ILO (2018): ILOSTAT Database.

Difficulty in obtaining adequately paid, decent work has led to economic discouragement and social marginalisation, particularly among youth and women. Less than one-half of all young people aged 15-24 participate in the labour market in Brunei Darussalam, Singapore, Philippines, Thailand, Malaysia and Indonesia (World Bank, 2018). However, in Cambodia three-quarters of young people are economically engaged. Given that ASEAN countries tend to have a higher share of youth and young adult populations than most developed countries, young people's lack of economic engagement has crucial implications for growth and productivity.

In every ASEAN country, women have lower labour force participation rates than men, with the gender gap exceeding 25 percentage points in Indonesia, Myanmar, Malaysia and the Philippines (Figure 1.8). Moreover, when women participate in the labour market, they often obtain lower-paid, less senior positions than men. Except for the Philippines and Brunei Darussalam, less than one-third of middle and senior managers in the ASEAN countries for which there is data are women (Figure 1.9). 
Figure 1.8. Labour force participation by gender in ASEAN countries, 2017

$\%$ of females and males (15 and older) in the labour market

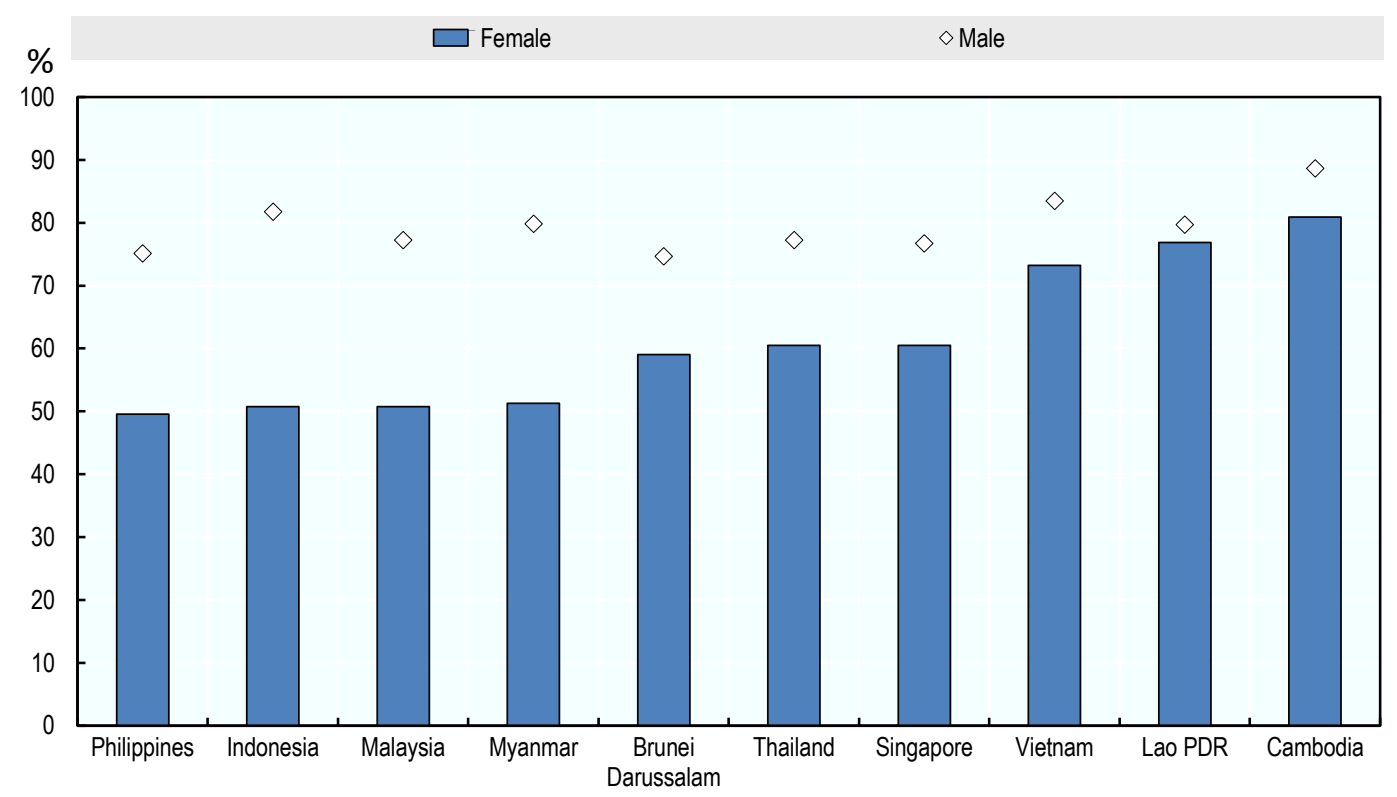

Source: World Bank, World Development Indicators database (accessed 3 March 2018).

Figure 1.9. Women's percentage share of senior and middle management positions in ASEAN countries, latest available data

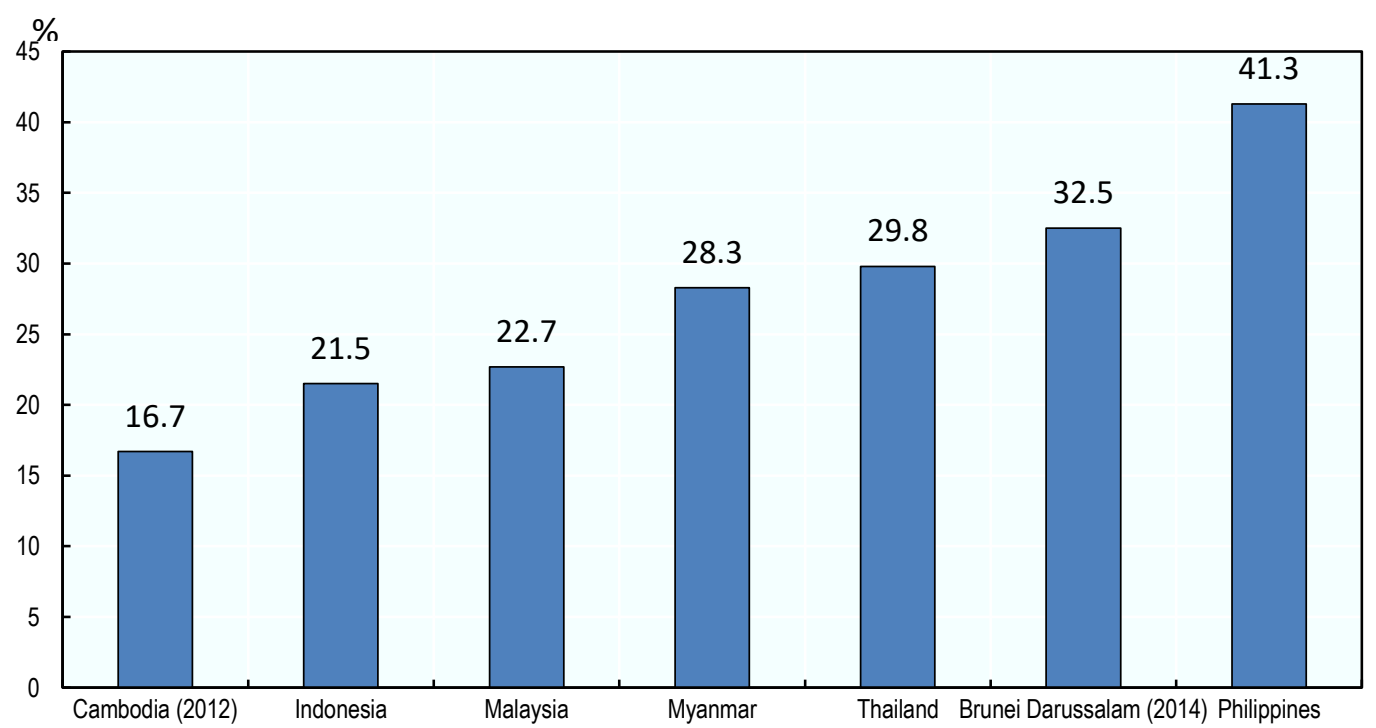

Source: ILOSTAT

Given that gender often intersects with age in determining women's employment outcomes, young women are more prone to economic discouragement and social marginalisation than young men across the ASEAN region. Indeed, in several countries in the region (Brunei Darussalam, the Philippines and Thailand), less than one-third of females aged 15-24 
participate in the labour market (World Ban, 2018), despite women's educational attainment levels having risen significantly over the past few decades (ASEAN Secretariat, 2016).

Inequality matters, not simply in its own right, but also because it has consequences for sustained growth and poverty reduction. Analyses show that inequality can dampen the poverty reduction impact of growth, as well as hamper growth through a number of economic, social, and political mechanisms (ADB, 2014a). These findings have particular relevance for the CLMV countries, which are seeking to close the growth gap with the wealthier countries in the region. Conversely, the foundations for future growth and poverty reduction can be strengthened if efforts are made to ensure that the benefits of development are shared broadly and equitably across populations.

According to the Asian Development Bank (2014a), the main drivers of economic growth in the ASEAN region - that is, technological change, globalisation, and market-oriented reform - are also the driving forces behind rising inequality in Asia. These processes have increased the returns to human capital and the premium that individuals with higher educational attainment levels and skills realise, but have also threatened the livelihoods of individuals who are unable to adapt to the demands of the rapidly changing environment. Thus, skills development has a key role to play in reducing inequality in the region.

Technical and vocational education and training (TVET) is increasingly being viewed as an antidote to the main developmental challenges in the ASEAN region, which have resulted in growing inequalities in wealth distribution (UNESCO, 2015). ${ }^{3}$ Whereas TVET was once regarded as a 'second-choice' educational option, recent evidence suggest that well-designed TVET programmes can be more effective than general (or academic) education for integrating groups that are marginalised (such as women and young people) into local labour markets and improving their earnings, thereby providing pathways to decent employment. Comprehensive 'second-chance' TVET initiatives, implemented in many countries to enhance the employability of disadvantaged and/or marginalised groups, have been found to be effective in reducing poverty, inequality and social exclusion, especially in developing countries. ${ }^{4}$ Evidence from international experience concerning TVET's impact on employment and wages (Section 2) and on poverty, inequality and social exclusion (Section 3) is explored below.

\footnotetext{
${ }^{3}$ Nevertheless, TVET has its critics and limitations. For example, TVET systems are often criticised as being expensive, yet inefficient and/or unresponsive to market forces (UNESCO, 2015).

4 'Second-chance' initiatives are non-formal programmes that provide individuals who left the education system early with a means to return to education and potentially acquire a qualification (Cedefop, 2016).
} 


\section{TVET's relative impact (versus general education) on employment and wages}

Education has a strong positive impact on individuals' employment prospects and wages, while secondary education is widely regarded as the minimum level required for securing and maintaining productive employment in today's complex globalised environment. Human capital theory, the dominant paradigm in the economics of education literature, posits that education and training make individuals more productive, which in turn increases their probabilities of being employed and earning higher wages (Carneiro, Dearden and Vignoles, 2010). Higher levels of education are linked to improved employment probabilities: for example, on average across OECD countries, $84 \%$ of tertiary graduates and $74 \%$ of upper secondary and post-secondary non-tertiary graduates are employed, compared to $56 \%$ of individuals without an upper secondary qualification (OECD, 2011). A strong significant relationship also exists between higher levels of education and earnings, with each additional year of full-time formal education translating into wage returns of around 8-10\% (Card, 1999).

Secondary education produces higher returns for women than for men, so ensuring that girls remain in school until at least secondary education completion can lead to greater gender equality. A study on returns to investment in education across 42 countries found that, while men experience higher returns to primary education than women $(20 \%$ versus $13 \%)$, women realise higher returns to secondary education than men (18\% versus $14 \%$ ) (Psacharopoulos and Patrinos, 2004). Women's secondary completion is also linked to a range of non-economic benefits. For example, women who have completed secondary education have a lower probability of marrying early, dying during childbirth or contracting diseases (e.g. HIV/AIDS), and have a higher probability of having fewer children, having healthier children and sending their children to school than women with less than secondary education (UNESCO, 2016a; World Bank, 2012). These progressive trends explain why the UN Sustainable Development Goals (SDGs) emphasise the retention of all children in school until completion of secondary education (SDG 4, Target 1). ${ }^{5}$

Which kind of secondary education - general/academic or TVET - produces the greatest benefits for individuals and economies? Global perspectives on this question have changed in line with the evolving skills needs of businesses. Until recently, general education was considered the more lucrative track, since it teaches transferrable skills that can be applied across a range of occupations and tends to offer greater access to decent, well-paid jobs. However, the recent surge in global youth unemployment has been found to stem from 'skills mismatches' produced by an overly theoretical approach to education that does not supply the specific technical and vocational skills increasingly demanded by employers (Biavaschi et al, 2012; UNESCO-UNEVOC, 2013). Hence, in many countries, there is high youth unemployment at the same time as there are skills shortages in key sectors of the economy (ILO, 2014a). According to ManpowerGroup, 40\% of employers globally report having problems filling job vacancies, while a recent study on skilled labour in five

5 The SDGs were ratified by 193 UN Member States on 25 September 2015 (see https://sustainabledevelopment.un.org/sdgs). 
ASEAN member countries ${ }^{6}$ found that a shortage of industry-ready skilled workers is one of the biggest challenges facing the countries, although the nature and extent of skills gaps vary widely across the countries (ManpowerGroup, 2016; Song and Tang, 2016). It is within the context of skills gaps and mismatches that TVET has become a key priority in the global development agenda.

Yet, assessing the relative impact of TVET versus general education on graduates' probabilities of being employed and earning higher wages is not a straightforward task for several reasons. First, few countries routinely and rigorously evaluate their TVET systems; hence, there is a shortage of appropriate data from which to draw conclusions (Biavaschi et al, 2012). Reliable evidence on TVET's impacts is especially scarce for developing countries, since rigorous evaluation exercises are costly to conduct (Kingombe, 2012). Second, in most countries TVET and general education attract different kinds of learners and have different programme features, thus introducing biases that need to be corrected to accurately compare returns across the two educational tracks (Eichhorst et al, 2012). For example, TVET students often come from lower socioeconomic backgrounds and tend to have weaker academic abilities and motivation than general education students. Likewise, general education programmes tend to have a longer duration and involve higher costs than TVET programmes (Hoeckel, 2008). Third, definitions of TVET and TVET systems vary across countries, making it difficult to extrapolate results across very different kinds of school-based, firm-based and apprenticeship programmes (Hanushek, Woessmann and Zhang, 2011). Fourth, in some instances employment and wage outcomes do not reflect education and training quality, but instead dynamics within the labour market. For example, the availability of jobs may be greater in some fields than in others due to differences in labour intensity, or wages may be lower for some occupations than others, despite requiring higher skills.

Notwithstanding these issues, several observations may be made regarding the relative impact of TVET versus general education on graduates' employment rates and wage levels.

\subsection{Evidence from developed countries}

Looking first at the experiences of developed countries, for which there is a fairly strong evidence base, suggests the following trends:

1. TVET tends to result in faster school-to-work transitions than general education. Studies comparing employment rates of TVET versus general education graduates at upper secondary school level in the European Union, at upper secondary and tertiary levels in the USA, UK and France, and between skilled vocational versus university graduates in Australia, confirm this finding (Cedefop, 2013a; NCVER, 2001; Ryan, 2001).

2. The countries with the quickest education-to-employment transition rates among secondary TVET graduates are those with embedded dual apprenticeship systems, where school-based (vocational) education is combined with structured onthe-job training (Quintini and Manfredi, 2009). Evidence from Germany and France shows that apprenticeship training results in faster and more organised entry into the labour market than purely school-based TVET programmes, because closer links are established with the private sector (Winkelmann, 1996; Bonnal, Mendes and Sofer, 2002). Countries with well-established dual training systems, such as Denmark, Austria and Germany, have

\footnotetext{
${ }^{6}$ The five countries covered by the study are Singapore, Malaysia, Thailand, Indonesia and the Philippines.
} 
been more successful than other countries in maintaining low youth unemployment rates and lower repeated unemployment spells among youth (Quintini, Martin and Martin, 2007).

3. Although TVET graduates experience faster initial entry into the labour market than general education graduates, their employment advantage diminishes with age, albeit close to retirement age (Hanushek, Woessmann and Zhang, 2011). Evidence from eleven OECD countries with sizeable TVET systems shows that, among younger cohorts, TVET graduates tend to have higher employment rates than general education graduates; however, later in life, at around the age of 50, the trend reverses and general education graduates experience higher employment probabilities than TVET graduates, with the employment differences between the two groups becoming statistically significant for individuals aged 56-65 (Hanushek et al, 2017). This over-time decrease in TVET graduates' comparative advantage in the labour market is attributable to TVET graduates' occupation-specific knowledge becoming more quickly outdated than general education graduates' theoretical knowledge, as well as to TVET graduates' lower access to higher education opportunities than general education graduates in many countries (Biavaschi et al, 2012). Thus, improving their access could potentially extend TVET's benefits.

4. Nevertheless, in terms of earnings, secondary TVET graduates seem to do as well as or better than secondary general education graduates over the lifecycle of their careers. Evidence from the United States shows that TVET graduates spend more time in employment, get better jobs and earn significantly more than their general education counterparts (Bishop and Mane, 2004). In European countries, the wage differential that once existed between the two educational tracks has now closed as a result of a growing demand for TVET skills (Cedefop, 2013b).

5. However, TVET and general education graduates experience different wage patterns across their careers. Consistent with the earlier findings on employment patterns, TVET graduates' wages tend to be higher than those of general education graduates at the beginning of their careers, but over time the wage relationship reverses and general education graduates' wages exceed those of TVET graduates (Hanushek, Woessmann and Zhang, 2011). The crossover age for wages comes much earlier than for employment rates: general education graduates begin to earn more than TVET graduates at around 30 years of age, with a flattening off of the wage differential between the two education tracks at around age 50 (Hanushek et al, 2017).

6. Wage returns across different TVET programmes vary according to the following factors:

- Qualifications level: TVET's relative impact on wages tends to increase at higher education levels. For example, in France and the UK in the 1990s, secondary TVET graduates earned $10 \%$ less than their general education counterparts, but postsecondary TVET graduates earned $21 \%$ more (Ryan, 2001). However, the wage impacts of not completing a TVET qualification are mixed: in Australia TVET training that does not lead to a qualification has no discernible impact on wages, while in Europe ever having received TVET training has a 3\% positive impact on wages (Cedefop, 2011a; Ryan, 2002).

- Modality of training: Students enrolled in apprenticeship programmes tend to have higher completion rates than students enrolled in purely school-based TVET programmes, because work placements make in-class learning more relevant, which increases students' motivation and boosts their performance (Alet and Bonnal, 2011). Moreover, because of their practical skills and work experience, 
graduates of dual training programmes tend to have better job matches and attract higher wages at the beginning of their working life than graduates of purely schoolbased TVET programmes (Ryan, 2001). However, dual training graduates' relative wage advantage tends to decline or vanish over the longer term, resulting in lifetime earnings that are not discernibly different to those of purely school-based TVET graduates (European Commission, 2013). Dual training programmes produce declining returns compared to school-based TVET because of their greater emphasis on occupation-specific versus general skills (Hanushek et al, 2017). Thus, some studies highlight the importance of strengthening the foundations of basic knowledge taught in TVET to increase graduates' employability and wages over a longer lifecycle (OECD, 2006).

- Relevance of training: Returns to TVET are higher if training closely matches available employment opportunities. For example, in Israel in 1983, secondary TVET graduates earned 8-10\% more than academic high school graduates if they entered an occupation matching their qualifications; however, if TVET graduates worked in occupations unrelated to their training, there was no wage differential between the groups (Neuman and Ziderman, 1999).

- Level of focus on and investment in TVET: Targeted investment to improve the quality of TVET, especially when combined with policies to promote TVET's benefits to employers, can have a significant positive impact on graduates' productivity and wage levels (Cedefop, 2011b). In the Republic of Korea, where the state has invested heavily in TVET to produce skilled workers for the country's manufacturing and construction industries, secondary TVET graduates now earn about 30\% more than their general education counterparts (Kim, 2013).

- Programme choice: National-level data across OECD countries suggests that relative wage returns to TVET vary substantially depending on students' field of study (Hoeckel, 2007). For example, in Chile in 2010, returns to four different categories of TVET ranged from USD 114 to USD 447 per month (Bucarey Castro, 2013). Thus, collecting and reporting data on the labour market impacts of specific TVET programmes can enable individuals to make more informed choices about their education and career.

7. TVET's relative impact on graduates' employment rates and wage levels differs by sex. In Australia, female TVET graduates are more likely to be unemployed or part-time employed and to earn lower wages than male TVET graduates (NCVER, 2000; Watson, 2000). Similar trends have been observed in the USA, Europe and Israel (BMSFS, 2009; Neuman and Ziderman, 2003; NWLC, 2002a). Male-female differences in labour market outcomes are partly the result of sex segregation in TVET: across the world, women tend to enrol in traditionally 'female' courses that do not provide them with the technical skills or training to access higher-wage jobs. Sex segregation in TVET takes place for a variety of reasons, including biased or inadequate counselling, incomplete information on the consequences of training choices, and sexual harassment of women who enrol in traditionally 'male' courses (NWLC, 2002b). Introducing measures to increase women's access to and retention in traditionally 'male' TVET programmes has been shown to improve women's relative labour market outcomes: countries that have implemented policies to reduce sex segregation in TVET and to create more female-friendly TVET school environments have narrower male-female employment and wage gaps (Månsson and Färnsveden, 2012). 


\subsection{Evidence from developing countries}

Turning now to the less well-documented experiences of developing countries, the following trends are evident.

1. Formal school-based TVET is a less prevalent form of skills training than are informal apprenticeships, which take place outside of the formal education system. ${ }^{7}$ The main reason for this is that in most developing countries a large proportion of young people do not complete lower secondary school, the minimum level for accessing most formal TVET programmes (Global Partnership for Education, 2014; Maclean and Pavlova, 2013). ${ }^{8}$ By contrast, informal TVET ${ }^{9}-$ which is provided by micro or small enterprises in the informal sector of the economy - requires no formal qualifications and avoids the direct and indirect costs of formal schooling, making it the most accessible and cost-effective training route for young people from poor households. ${ }^{10}$

2. Secondary school graduates across both education tracks tend to experience slower school-to-work transitions than their counterparts in developed countries, and TVET graduates tend to have lower access to decent formal sector job opportunities than general education graduates. In most developing countries, job growth in the formal sector is slow, so informal employment rates are high (Kingombe, 2012). Most secondary school graduates would prefer to work in the formal sector, where minimum wage rates and other labour regulations apply, but most formal sector employers prefer general education graduates to TVET graduates for historical, social and cultural reasons, as well as quality concerns (Atchoarena and Grootings, 2009). Hence, formal TVET graduates are often forced to work in informal sector jobs or, if they obtain formal jobs, end up in semiskilled rather than higher-skilled positions (Kingombe, 2012). However, recent studies show that access to well-designed labour intermediation services can reduce job discrimination, which affects less well-connected groups in developing countries (Mazza, 2016).

3. Nevertheless, wage returns to formal TVET can sometimes be higher than those for general education. For example, a recent review has found that returns to secondary TVET are higher than returns to secondary general education in Thailand,

\footnotetext{
7 'Formal TVET' is defined as 'instruction given in education and training institutions or specially designed training areas, including enterprises in formal apprenticeship systems, [where] training is structured and systematic and follows pre-defined content and precise learning objectives' (ILO, 2011). By contrast, informal apprenticeships are a traditional form of training, wherein a young person (the apprentice) learns the skills for a trade or craft by working alongside an experienced master craftsperson (ibid).

${ }^{8}$ Few countries in the world $(24 \%)$ offer formal TVET at lower secondary level (Maclean and Pavlova, 2013).

9 'Informal TVET' is used interchangeably with 'informal apprenticeships' throughout this paper. Informal TVET is defined as 'organised education and training outside of the formal education system where learning results from daily life activities related to work' (UNESCO-UNEVOC, 2014).

${ }^{10}$ However, there are costs to informal TVET: the trainer's costs include the time invested in training as well as any allowances, in-kind remuneration (such as meals) or wages given to the trainee; and the trainees' costs include their labour, plus any fees charged by their trainer or training firm (ILO, 2011).
} 
Indonesia (for older cohorts of TVET graduates), Cambodia and Turkey, but not in Iran, Indonesia (for younger cohorts of TVET graduates) or Tanzania (Eichhorst et al, 2012).

\section{Wage returns to formal TVET seem to vary according to the following factors:}

- Choice of programme: Wages vary by occupation, so the choice of which TVET programme to pursue can have a significant impact on graduates' current and future earnings. In Peru in 2014, the average wage returns realised by tertiary TVET graduates of science, engineering and manufacturing programmes were $71 \%$, compared to $49 \%$ for university graduates with degrees in the same subjects; yet the opposite was true for individuals who had studied arts and architecture university graduates realised average wage returns of $48 \%$, compared to $16 \%$ for tertiary TVET graduates (Espinoza and Urzua, 2015). Similar trends have been noted among upper secondary TVET graduates in Brazil in 2007: graduates of manufacturing programmes earned $32.9 \%$ higher wages than their general education counterparts, while graduates of health programmes earned $12.7 \%$ lower wages than their general education equivalents (Almeida et al, 2015). In many developing countries, social norms, quality concerns and lack of information concerning potential returns to specific TVET programmes have resulted in a limited uptake of TVET, even in fields of study where TVET returns exceed those of general education (Paz, 2017; Urzua, 2017).

- Level of focus on and investment in TVET: In many developing countries, low returns to TVET reflect poor training quality, which in turn is the result of inadequate budgetary allocations and/or weak monitoring and evaluation (Ul-Haq and Haq, 1998). While targeted investments to improve TVET quality and promote TVET's benefits to employers could enhance TVET graduates' wage returns and capabilities, governments' ability to increase TVET funding is often tied to national income. Thus, relative returns to TVET tend to be higher in middle-income than in low-income countries (Bennell, 1996).

- Relevance of training: In many developing countries, formal TVET is publicly provided with little private sector involvement, which results in training being delinked from labour market needs and/or curricula being outdated (Glick et al, 2015). Evidence from Brazil, Chile and Peru shows that private TVET institutions - in particular, those that are publicly financed but privately managed - tend to produce higher wage returns for TVET graduates than public TVET institutions (Almeida et al, 2015; Espinoza and Urzua, 2015). Returns to TVET are also higher if training matches available employment opportunities. Thus, upper secondary TVET graduates of manufacturing programmes in Brazil in 2007 earned 34.5\% higher wages than their general education counterparts if they worked in a field related to their training, but only $31.8 \%$ higher wages if they worked in an unrelated field (Almeida et al, 2015).

- Pathways to further education: In many developing countries, secondary TVET graduates do not have access to further or higher education and are thus forced to exit the education system earlier than secondary general education graduates, resulting in their lower relative wages (Adams, 2007). Where developing countries have taken steps to improve TVET graduates' access to further and higher education, perceptions of TVET as a 'dead end' have changed and relative returns to TVET have increased (ibid.). For example, in Thailand, where upper secondary TVET graduates now have equivalent access to tertiary education as upper secondary general education graduates, TVET graduates' wages are now higher 
than those of general education graduates (Hawley, 2003; Moenjak and Worswick, 2003).

5. However, contrary to patterns observed in developed countries, in developing countries TVET's relative impact on wages does not necessarily increase at higher qualifications levels. A study of returns to TVET in Tanzania from 1997 to 2000 showed that at lower levels of education returns to TVET do not significantly differ from and can sometimes exceed the returns to general education. However, at higher levels of education, returns to general education substantially exceed the returns from TVET (Kahyarara and Teal, 2008). Likewise, research on returns to higher education in Chile and Colombia from 2008 to 2010 showed that a significant proportion of tertiary-level TVET graduates would have been better off financially had they not invested in post-secondary training (GonzalezVelosa et al, 2015). In both countries, this anomaly arose because improvements in TVET graduates' access to higher education were not accompanied by sufficiently strong mechanisms to assure the quality and relevance of TVET training.

6. Sex segregation in formal TVET is endemic in developing countries, so female TVET graduates' employment rates and wage levels tend to be lower than those of male TVET graduates. In many developing countries, gender norms, standards and practices limit women's access to traditionally 'male' TVET courses. Self-selection by women into less lucrative TVET programmes, combined with gender-biased labour market practices in most developing countries, means that female TVET graduates tend to have slower school-to-work transitions and obtain poorer-quality and lower-paid jobs than male TVET graduates (Adams, 2007).

7. Nevertheless, possessing a TVET qualification can offer pathways to employment for women, thereby improving their living conditions. Evidence from Turkey suggests that secondary TVET has a much stronger positive impact than secondary general education on women's labour market participation rates and employment probabilities, although not their wage levels (Tunali, 2003). Nevertheless, women's employment - even at low wages - can improve women's social standing in their households and communities and reduce women's financial dependence on their male partners, making them less susceptible to domestic violence (World Bank, 2012).

8. Little reliable information is available regarding the impact of informal TVET on graduates' employment rates and wage levels. However, the following trends may be inferred:

- Relative impact on employment: Informal TVET graduates likely have faster education-to-employment transitions than either formal TVET or general education graduates, as they are trained by employers in the largest sector of work in developing countries (Biavaschi et al, 2012). However, informal TVET graduates' employability is dependent on not only the relevance but also the quality of the training they receive, which can vary considerably across training providers: some apprentices may be taught by skilled master craftsmen who ensure that they receive high quality training to become master craftsmen themselves, while others may be exploited as cheap labour by trainers who fail to impart their skills to keep apprentices dependent on them (ILO, 2011). In most countries, informal TVET training is not certified or recognised, which limits graduates' labour mobility and access to further (formal) education, which in turn can affect their future employability and wage levels.

- Relative impact on wages: Informal TVET graduates tend to earn considerably more than untrained workers in the informal economy, since completion of an 
apprenticeship is often required for promotion from unskilled to skilled positions or to become a master craftsman (Biavaschi et al, 2012). However, they likely earn less than formal TVET or general education graduates, since informal TVET is often not linked to the formal education system, which limits informal TVET graduates' access to further education and formal sector jobs. Their long-term wages may also be depressed compared to those of formal TVET and general education graduates, since informal apprenticeships normally take place in traditional crafts sectors, where technological innovation and productivity gains are low, and because lack of certification of informal TVET graduates' skills and experience in many developing countries limits their access to upgrading or retraining opportunities.

- Impact of sex differences: Gender discrimination combined with the preponderance of male-dominated trades in the informal sectors of most developing countries means that women often have lower access to informal apprenticeships than men (ILO, 2011). Women also face higher obstacles than men in getting hired following their training and in gaining access to well-paid jobs. In the informal sectors of most developing countries, men tend to be over-represented in the top-earning segment (employers), while women tend to be over-represented in the bottom-earning segments (home workers and unpaid contributing family workers); the relative shares of males and females in the intermediate-earning segments (own-account operators and wage workers) vary across sectors and countries (Månsson and Färnsveden, 2012). Female entrepreneurs also have lower access to credit and networks than male entrepreneurs, which can affect their long-term earnings (World Bank, 2012).

\subsection{Comparison between developed and developing countries' experiences}

Synthesising the evidence across both developed and developing countries, the findings show that:

- Formal TVET tends to result in faster school-to-work transitions and higher wages than general education in developed countries, but in slower school-to-work transitions and lower access to decent, high-quality jobs - albeit with mixed wage impacts - compared to general education in developing countries. The key differences between developed and developing countries in terms of formal TVET's relative impact on employment and wages may be explained by: TVET's low status (and often quality) in developing countries; limited private sector involvement in formal TVET in developing countries; and low availability of formal sector jobs, combined with low access to labour intermediation services in developing countries. Where developing country governments have taken steps to address these issues, formal TVET graduates' returns are closer to and sometimes exceed those of general education graduates.

- Both in developed and developing countries, TVET's relative impact on graduates' employability and wages is negatively affected by TVET graduates' weaker access to further education than general education graduates, lack of information on the labour market impacts of specific TVET (and general education) programmes, and the failure of TVET systems to deliver the level and mix of skills demanded in the labour market - in particular, workplace training and general transferrable skills.

- Informal TVET offers young people from poor families, as well as those who have exited the education system early, a valuable opportunity to improve their 
employability and wages. However, informal TVET's positive labour market impacts are offset by lack of consistency in training quality, low productivity and innovation within informal sector firms, and a lack of formal mechanisms for validating and certifying informal TVET graduates' skills and experience in many developing countries.

- In both developed and developing countries, women have lower access than men to high-performing TVET training and decent job opportunities, which limits the role that TVET can play in reducing poverty and inequality. Nevertheless, possessing a TVET qualification can open up employment opportunities for women, thereby raising their living standards and social standing, and can generate myriad non-economic benefits for women and their children.

\subsection{Key takeaways for closing the gap between developed and developing countries}

To close the gap between developed and developing countries in terms of TVET's effectiveness in offering pathways to decent employment, there is a need for: sufficient political and financial commitment to raising the quality and status of TVET; greater private sector involvement in designing, financing and implementing TVET; better data on the labour market impacts of TVET (and general education) programmes; improved articulation between informal learning and formal skills training within a broader lifelong learning framework; and measures to reduce gender bias in TVET and the labour market. Measures to raise the productivity of informal sector firms and to promote job growth in the formal economy could also enhance TVET outcomes. 


\section{TVET's impact on poverty, inequality and social exclusion}

In addition to formal and informal TVET programmes, many countries implement nonformal TVET ${ }^{11}$ programmes to integrate disadvantaged and/or marginalised groups into the labour market. Also referred to as 'second-chance' initiatives, these programmes aim to reduce poverty, inequality and social exclusion by preparing school-leavers for employment. While some second-chance initiatives target adults, most focus on young people, partly because returns to investment in training youth accrue over a longer time period, so tend to be higher (Carneiro and Heckman, 2003). ${ }^{12}$

However, assessing the impacts of second-chance initiatives can be problematic, since the evidence base on these programmes tends to be patchy. For example, while every intervention included in the World Bank's Youth Employment Inventory (YEI) in 2014 had been subject to some kind of evaluation, only $12 \%$ had been rigorously evaluated using a methodology (for example, control groups) to estimate net impact, and only $3 \%$ had been subject to a cost-benefit analysis as well as an impact evaluation (Rinne and Eichhorst, 2015). ${ }^{13}$ Rigorous evaluations exist mainly for programmes implemented in developed countries, but are rare for those in developing countries.

\subsection{Impact on poverty}

Nevertheless, trends observed across evaluations of youth-focused second-chance initiatives suggest that the programmes tend to be effective in reducing poverty among beneficiaries. For example, the majority (76\%) of interventions included in the YEI have had a positive impact on participants' employment rates and/or wage levels; only $8 \%$ of interventions have had a negative impact, while $16 \%$ have had no impact (Rinne and Eichhorst, 2015). The programmes' positive effects have been greater in developing countries than in developed countries. A systematic review of 97 youth-focused active labour market programmes worldwide confirms these results: it found that skills training programmes have had a positive impact on participants' employment and wages, especially in low- and middle-income countries (OECD, 2016). Likewise, a meta-analysis of 113 impact evaluations representing 107 youth-focused interventions in 31 countries concluded that both skills training and entrepreneurship promotion initiatives have had a positive and statistically significant impact on participants' employment and earnings, with a higher impact on their earnings than on their employment and with larger programme effects in

\footnotetext{
11 'Non-formal TVET' is defined as 'organised and systematic learning activity conducted outside the formal education system' (UNESCO-UNEVOC, 2014). Professional development programmes fall under the heading of non-formal TVET but are not covered in this section, since they tend to benefit educated workers rather than school-leavers (Vignoles et al, 2004).

12 Another reason is that, in most countries, youth unemployment rates exceed adult rates (ILO, 2014a).

13 The Youth Employment Inventory (YEI) is a database of post-formal schooling interventions designed to facilitate the transition of disadvantaged youth into the labour market. In 2014 the YEI consisted of 730 youth-focused interventions, of which $82 \%$ involved some form of skills training (Rinne and Eichhorst, 2015).
} 
low- and middle-income countries than in high-income countries (Kluve et al, 2017; Kluve, 2016).

\subsection{Impact on inequality}

Impact assessments show that second-chance initiatives can also play a role in reducing inequality. The meta-analysis of 113 impact evaluations representing 107 youth-focused interventions concluded that skills training programmes have had the greatest positive impacts on the most disadvantaged youth - those from low-income households, with low levels of education and/or exhibiting strong disadvantages in the labour market (Kluve et al, 2017; Kluve, 2016). It also found that skills training programmes often lead to an improvement in the quality of jobs (as measured by contract and job type) that participants obtain, especially in low- and middle-income countries. A review of youth training programmes in the Latin America and the Caribbean region found similar results: that the initiatives have had a greater positive impact on the labour market outcomes of the most disadvantaged groups - such as women, the youngest and the least educated - compared to other beneficiary groups (OECD, 2016). However, the review noted that employment, formality and wage effects differ across subgroups: for example, female beneficiaries tend to experience larger employment and wage gains than male beneficiaries, while male participants tend to obtain better quality jobs than female participants.

\subsection{Impact on social exclusion}

Impact evaluations also suggest that second-chance initiatives can promote inclusion and engender healthier and more peaceful attitudes and behaviours. Well-designed skills training interventions have been found to increase young people's economic, social and political engagement in addition to improving their employment outcomes (Offerdahl et al, 2014). Moreover, simply participating in non-formal TVET has been shown to raise the self-esteem and social standing of marginalised youth in fragile and conflict-affected settings (Petersen, 2013). Some of the reported positive impacts of multi-component second-chance initiatives - which combine, for example, TVET, life skills training, mentoring and conflict mediation - include better personal hygiene and protective sexual practices, decreased levels of depression and aggression, greater positivity about the future, less aggressive or violent behaviours, and a higher propensity among participants to contribute to their local community (USAID, 2013).

\subsection{Key takeaways for improving TVET's positive impacts}

Studies show that second-chance initiatives with the following features have the greatest positive economic and social impacts. First, comprehensive interventions that combine inclass learning with on-the-job training and labour intermediation services have more positive impacts on employability, earnings and especially job quality than programmes offering in-class training only (OECD, 2016; Fares and Puerto, 2009). Second, in terms of course content, programmes that include training in entrepreneurship and emphasise soft skills as well as technical skills have a more positive impact on employability, especially in low- and middle-income countries, than programmes without these components (Kluve et al, 2017; Kluve, 2016). Holistic programmes combining TVET, literacy and life skills training have the greatest positive impacts on participants' economic and social wellbeing 
(Jimenez et al, 2007). ${ }^{14}$ Third, entrepreneurship initiatives that offer start-up grants to mitigate the capital constraints faced by disadvantaged youth have a more positive impact on employability and business performance (profits and sales) than programmes without this feature (Kluve et al, 2017). Fourth, initial TVET programmes with a duration of four months or more, regardless of the number of training components that they include, have been found to have better labour market effects than shorter programmes (Kluve et al, 2017). Fifth, programmes that target specific groups and provide training stipends have been found to be more cost-effective than programmes with looser targeting and no participation incentives (OECD, 2016). Sixth, programmes that engage the private sector in their design and implementation have more positive impacts on employability, earnings and job quality than programmes with no private sector involvement (OECD, 2016; Jimenez et al, 2007). Finally, improving the articulation of second-chance initiatives with the formal education system by developing uniform standards and related testing and certification processes increase and extend programmes' positive impacts (Jimenez et al, 2007).

${ }^{14}$ According to the World Bank, combining livelihood skills training with adult literacy education can improve the living conditions of disadvantaged groups in three main ways: first, through an "empowerment effect", whereby learners' enhanced confidence and social resources motivate them to take initiatives to improve their livelihoods; second, through their new skills giving learners a competitive edge in market transactions in the informal economy; and third, because learning new vocational skills can lead to more productive agricultural or livestock practices. 


\section{Unleashing TVET's potential for fostering inclusive growth at the local level in the ASEAN region: key findings and good practice examples}

\subsection{Key findings on TVET's role in fostering inclusive growth at the local level in the ASEAN region}

The evidence presented in this paper suggests that TVET could be a powerful tool for addressing multiple developmental challenges and fostering inclusive growth at the local level in the ASEAN region. The findings of international studies show that:

- Formal TVET may be more effective than general education for tackling unemployment and underemployment, especially among women and youth, and providing graduates with pathways to decent employment, especially if the private sector is involved in the design and delivery of skills training and if TVET attracts sufficient political and financial commitment to raise the quality of programmes.

- Informal and non-formal TVET can play a role in reducing poverty, inequality and social exclusion by offering disadvantaged and marginalised groups the opportunity to acquire work-relevant skills, especially if graduates' skills and experience are formally assessed and certified.

However, TVET has not yet had a significant positive impact in the ASEAN region, partly because formal TVET enrolment rates are low. With the exception of Indonesia, upper secondary TVET enrolment rates across the region are low, falling below the world average (see Figure 4.1). In every country for which there is data, apart from Lao PDR, a higher share of male students participate in TVET than female students, and female TVET enrolment rates fall below both the world and developing country averages, except in Indonesia. Participation in TVET tends to be lower, with wider gender gaps favouring men, than participation in general secondary education (see Figure 4.2).

Another issue concerns regional disparities within countries in access to formal (and nonformal) TVET. For example, in Vietnam, access to TVET is more restricted in rural areas than in urban areas, irrespective of gender (Figure 4.3). Young people living in underserved areas that wish to learn the skills needed for a trade must therefore rely on informal TVET. After all, informal apprenticeships should (at least in theory) be available wherever there are MSEs - thus, both in rural areas (associated with agricultural work) and in regions that are underserved by formal and/or non-formal TVET opportunities. 
Figure 4.1. TVET enrolments as a percentage of gross upper secondary enrolments, by sex, in 2015

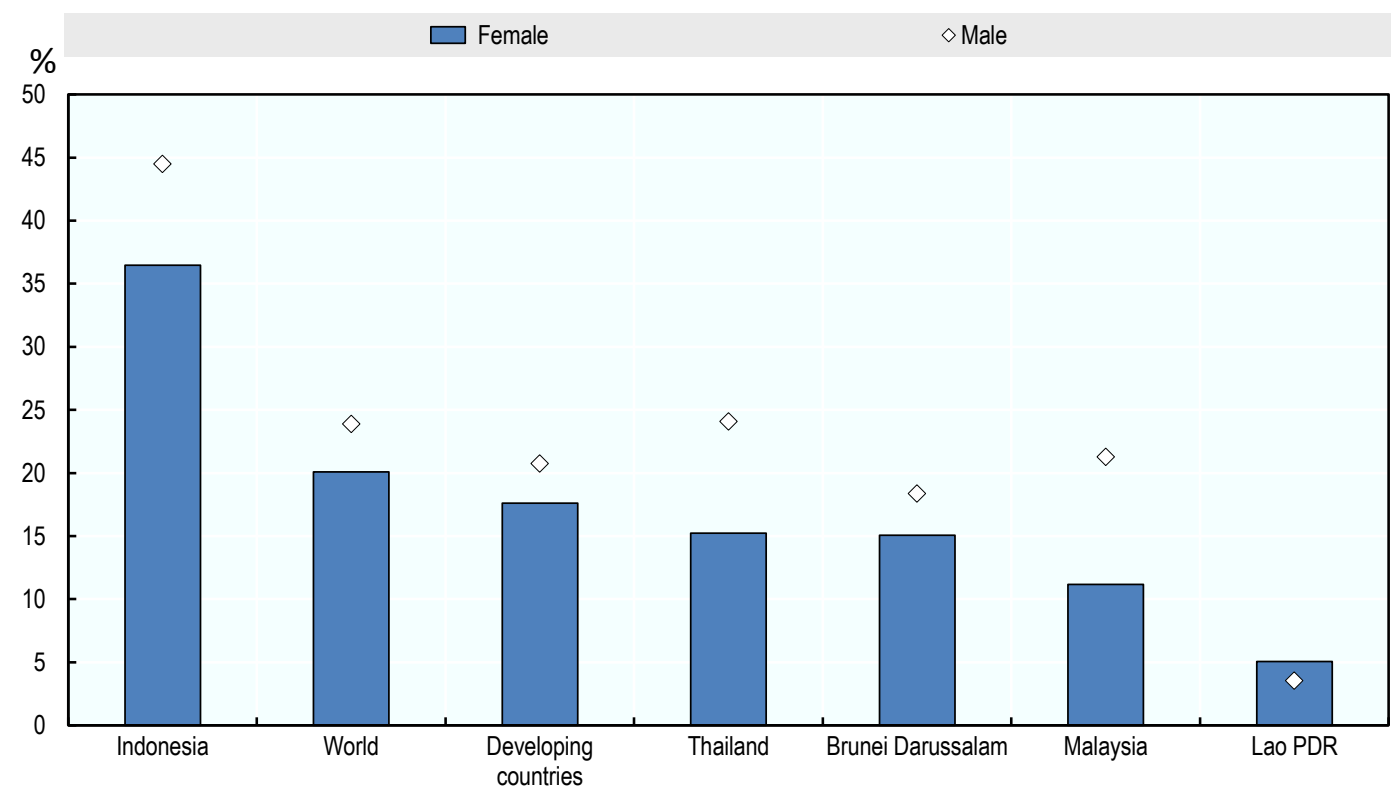

Source: UNESCO Institute of Statistics (2018), UIS.Stat database (accessed 13 March 2018).

Figure 4.2. Gross upper secondary enrolment ratio, by sex, 2015

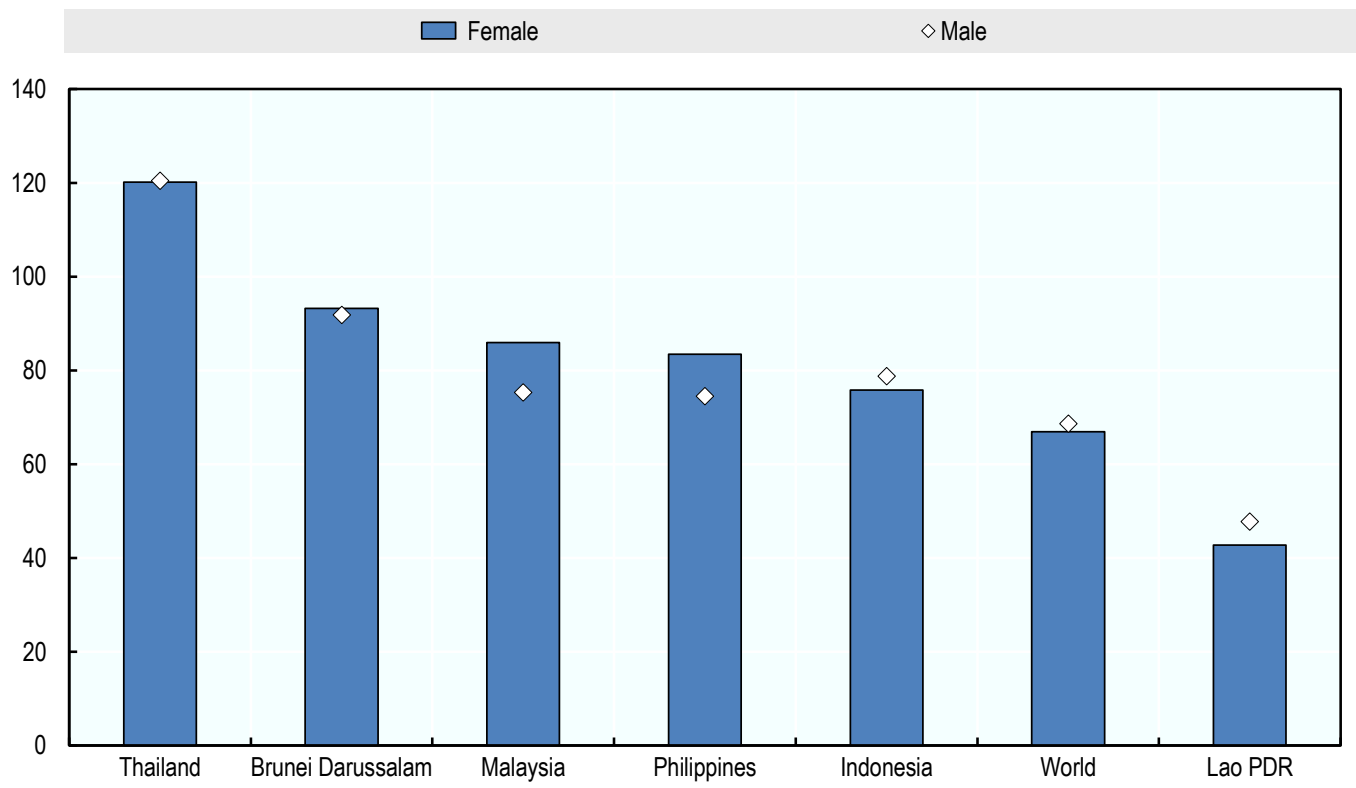

Source: UNESCO Institute of Statistics (2018), UIS.Stat database (accessed 13 March 2018). 
Figure 4.3. Access to TVET in Vietnam, by location and sex, SY2007

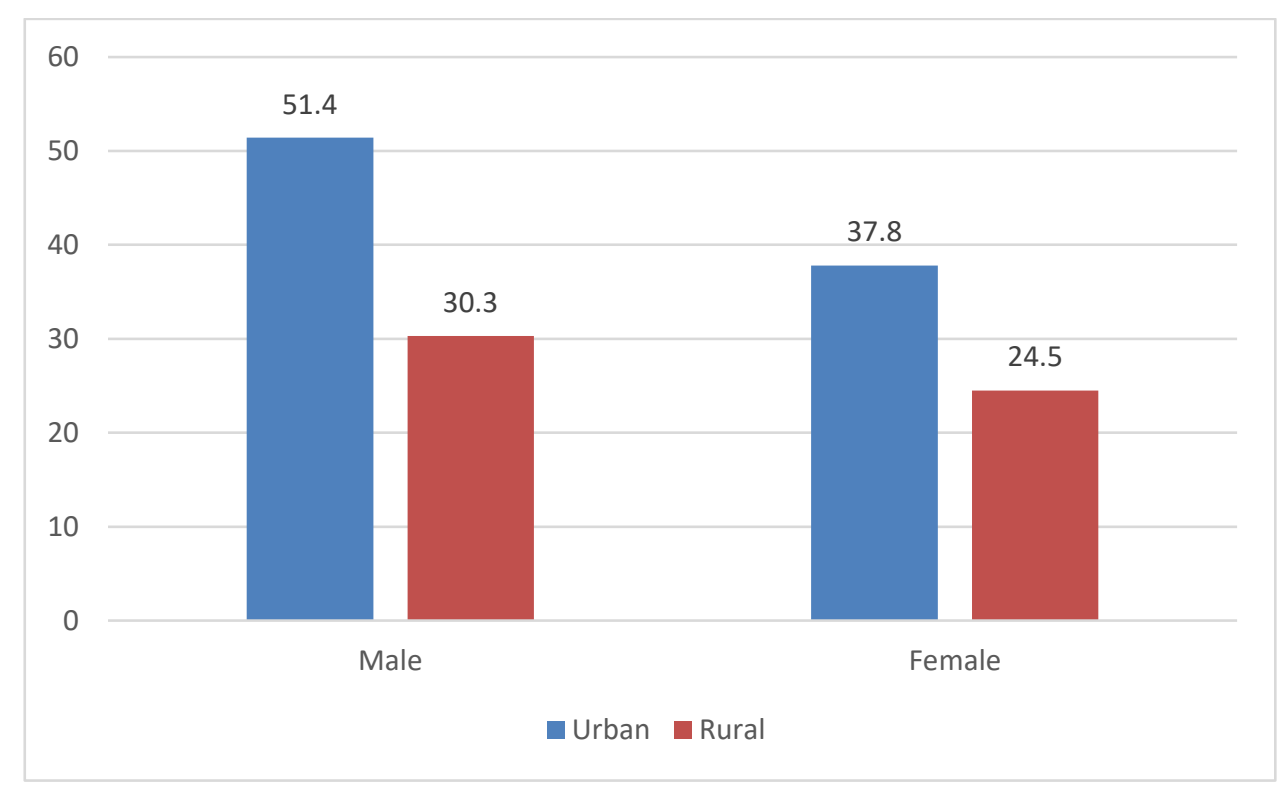

Note: $\mathrm{SY}=\mathrm{School}$ year

Source: ADB (2014b), Technical and Vocational Education and Training in the Socialist Republic of Viet Nam: An Assessment | Asian Development Bank, Asian Development Bank, https://www.adb.org/publications/technical-and-vocational-education-and-training-socialist-republic-vietnam-assessment (accessed on 02 March 2018).

In some countries, a lack of funds or underfunding of TVET relative to general education has affected TVET access and/or quality. Since TVET funding is often tied to national income, the poorer countries in the region often struggle to provide access to quality TVET, which explains why the TVET enrolment rate in Lao PDR is significantly lower than in the other ASEAN countries shown in Figure 4.1. Financial constraints inevitably affect TVET quality: for example, in both Myanmar and the Philippines, staff salaries and benefits account for the bulk (71\% or more) of spending in publicly-funded TVET programmes, leaving little money for staff training, learning materials, buildings and equipment (Palmer, 2017).

One important aspect of skills development is the responsiveness of TVET systems to the needs of local businesses and employers, as well as the aspirations of TVET learners. Yet TVET systems in the region tend to lack close partnerships between stakeholders, such as policymakers, employers, youth and local officials (Barr and Attrey, 2017). Moreover, as in other developing regions, countries in the ASEAN region do not have a strong tradition in social dialogue involving employer and worker organisations (OECD/ILO, 2017).

Despite these issues, a recent survey of ASEAN employers suggests that TVET is both valued and relatively well regarded in the region (ILO, 2014b). For example, the employers that were surveyed ranked 'vocational training' as the second most important type of training needed by workers, behind 'management and leadership preparation' ${ }^{15}$ Moreover, TVET graduates were judged to be more employable than high school graduates in every

15 'Customer service' was cited as the third most important type of training needed. 
country covered by the survey and more employable than college graduates in every country, apart from the Philippines and Cambodia (see Figure 4.4).

Figure 4.4. Employers' perceptions of education/training relevance, by track and level

$\%$ of employers who agree or strongly agree that the graduates meet their needs, by education type and level

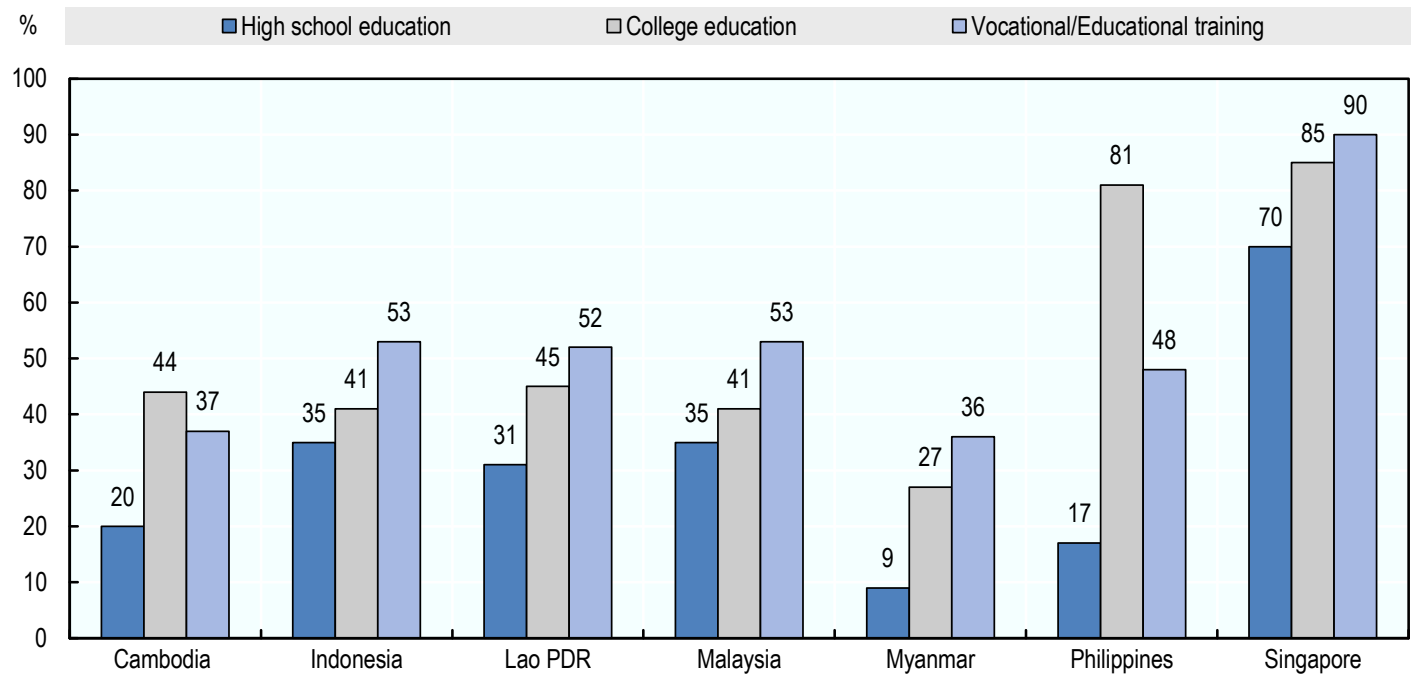

Source: ILO (2014b) Survey of ASEAN employers. Authors' calculations

However, only around half (53\%) of employers across the region agreed or strongly agreed with the statement that vocational education and training adequately matches their needs (Figure 4.5). Variation across countries in terms of employers' agreement with the statement partly reflects wealth differences. For example, $90 \%$ of employers in Singapore agreed or strongly agreed with the statement, compared to just over one-third in Myanmar and Cambodia (see Figure 4.4). The trends shown in Figure 4.5 indicate that there is still room for improvement across the region in terms of ensuring that TVET systems address and meet the needs of employers. 
Figure 4.5. Employers' level of agreement that TVET matches their skills needs

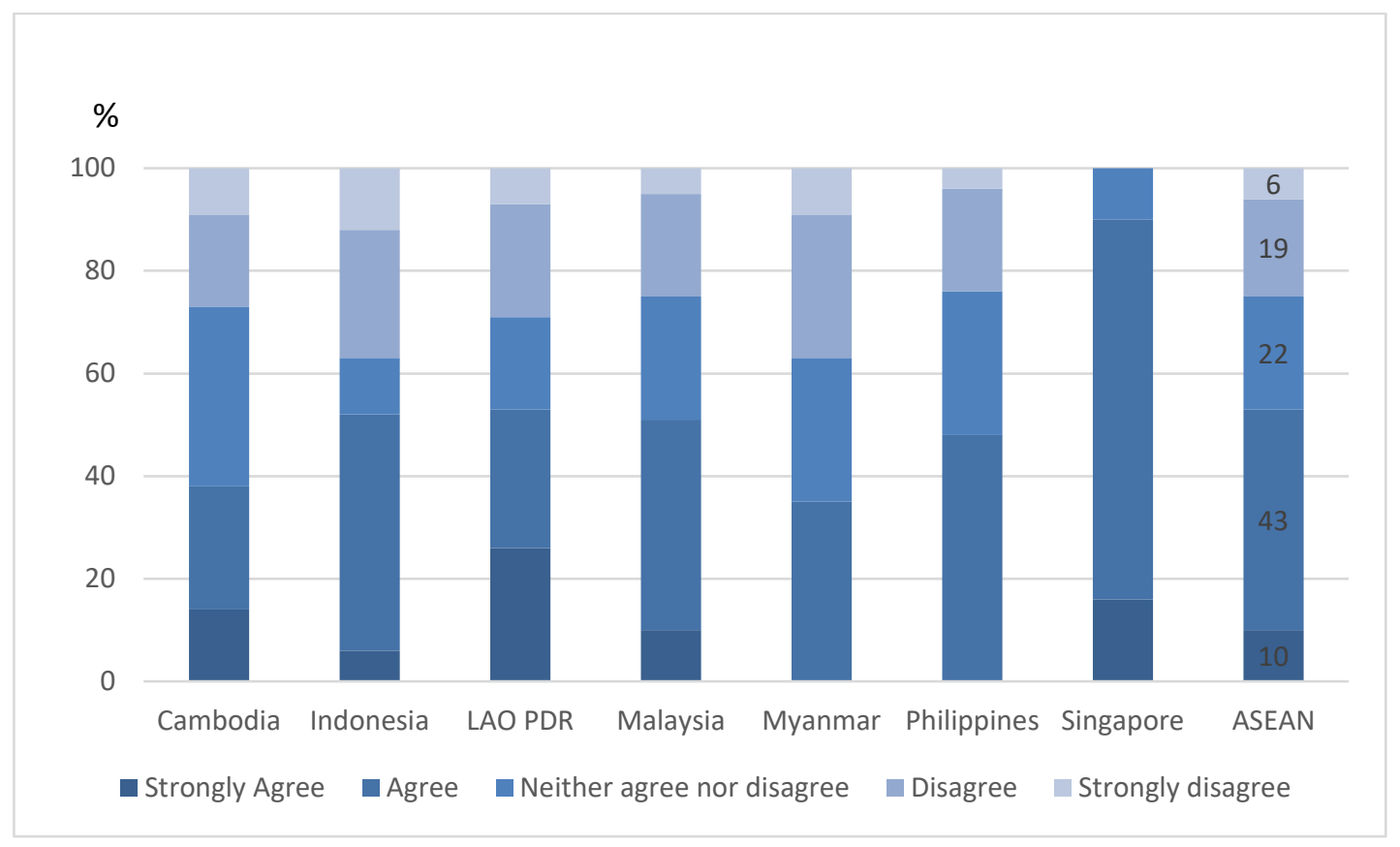

Source: ILO (2014b) Survey of ASEAN employers, Figure 9

To recap the findings of Sections 2 and 3 of this paper, some of the key ways to unleash TVET's potential for fostering inclusive growth at the local level include: improved political and financial commitment to raising the quality and status of TVET; increased private sector involvement in TVET financing, planning and implementation; improved guidance counselling and better data on the labour market and the returns to specific TVET programmes; uniform, recognised quality standards and related testing and certification processes; improved articulation between non-formal/informal learning and formal skills training within a broader lifelong learning framework; participation incentives (such as training stipends) to improve access to TVET by disadvantaged groups; and measures to reduce gender bias in TVET as well as in the labour market. Measures to raise the productivity of informal sector firms and promote job growth in the formal economy could also enhance TVET outcomes. In terms of training content, TVET programmes with the following features have been found to be most effective: comprehensive interventions combining in-class learning with on-the-job training and labour intermediation services; programmes offering training in literacy and soft/life skills, as well as technical skills; and entrepreneurship initiatives that include measures (such as start-up grants) to mitigate capital constraints.

\subsection{Examples of good practice in the ASEAN region}

Good practice examples demonstrating how some ASEAN countries have used TVET to improve economic and social outcomes are presented in Table 4.1 below. 
Table 4.1. Examples of good practice from the ASEAN region for harnessing TVET's potential for promoting inclusive growth at the local level

\begin{tabular}{|c|c|c|c|}
\hline $\begin{array}{c}\text { Programme } \\
\text { name (country) }\end{array}$ & Theme & Programme description & Outcomes \\
\hline $\begin{array}{c}\text { Gender } \\
\text { Responsive } \\
\text { Economic Actions } \\
\text { for the } \\
\text { Transformation of } \\
\text { Women (GREAT } \\
\text { Women) project } \\
\text { (Philippines) }\end{array}$ & $\begin{array}{l}\text { Empowering } \\
\text { women }\end{array}$ & $\begin{array}{l}\text { The main aim of the GREAT Women project is to improve } \\
\text { women's labour force engagement through } \\
\text { entrepreneurship. The project began in } 2006 \text { and } \\
\text { provides technical assistance and capacity-building } \\
\text { programs to support national government agencies in } \\
\text { promoting women's economic participation. } \\
\text { Core elements of the programme include: } \\
\text { - Strengthening the knowledge and awareness of } \\
\text { government officials in relation to gender analysis; } \\
\text { integrating gender in micro-enterprise development; and } \\
\text { gender sensitive planning and budgeting. } \\
\text { - Supporting education and skills development of } \\
\text { women micro-entrepreneurs and employees. Examples } \\
\text { include: sponsoring women to attend trade fairs and } \\
\text { exhibitions for product development, promotion and } \\
\text { market expansions; negotiation skills training; tailored } \\
\text { technical support and training in different localities. } \\
\text { - Public-private collaboration: } \\
\text { entrepreneurship training in collaboration with the } \\
\text { University of Philippines Institute for Small Scale } \\
\text { Industries and the Technical Education and Skills } \\
\text { Development Agency's Women's Centres. }\end{array}$ & $\mathrm{N} / \mathrm{A}$ \\
\hline $\begin{array}{c}\text { Strengthening } \\
\text { Technical and } \\
\text { Vocational } \\
\text { Education and } \\
\text { Training (STVET) } \\
\text { project } \\
\text { (Cambodia) }\end{array}$ & $\begin{array}{l}\text { Empowering } \\
\text { women }\end{array}$ & 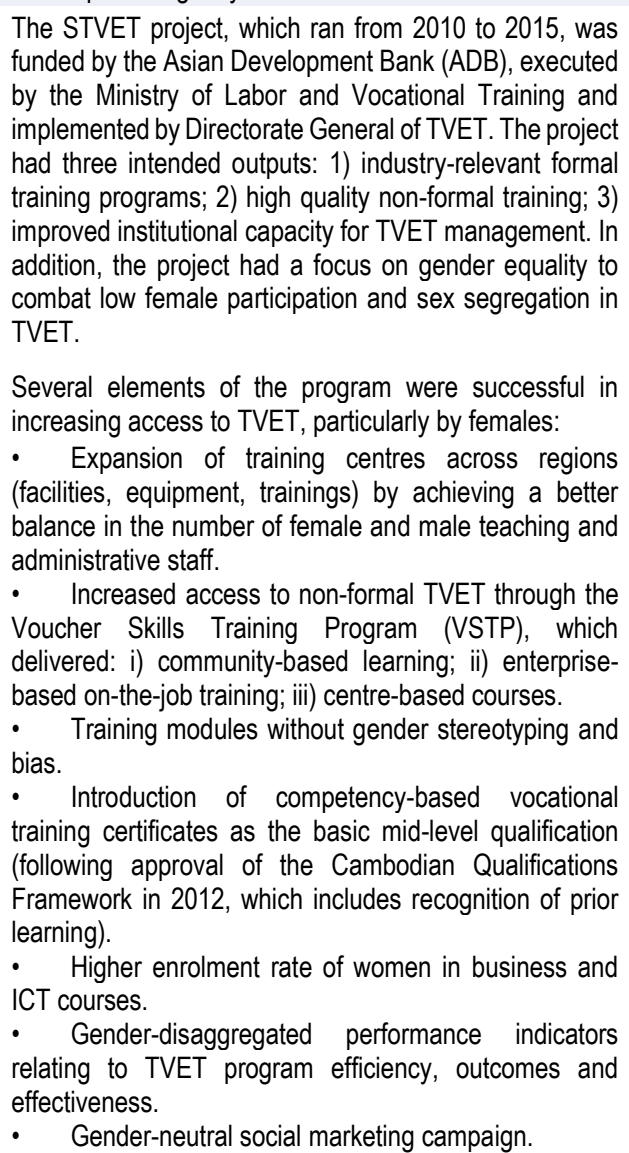 & $\begin{array}{l}\text { Following the project, } \\
\text { there was a } 21 \% \\
\text { increase in females } \\
\text { graduating with formal } \\
\text { TVET qualifications. } \\
\text { Nearly two-thirds of } \\
\text { the participants in the } \\
\text { demand-driven } \\
\text { Voucher Skills } \\
\text { Training Program } \\
\text { (VSTP) were female. }\end{array}$ \\
\hline $\begin{array}{c}\text { REACH } \\
\text { (Vietnam) }\end{array}$ & $\begin{array}{l}\text { Empowering } \\
\text { youth }\end{array}$ & $\begin{array}{l}\text { REACH, a local non-governmental organization, trains } \\
\text { young people - especially those from low-income }\end{array}$ & $\begin{array}{l}\text { Since 2008, REACH } \\
\text { has trained about }\end{array}$ \\
\hline
\end{tabular}




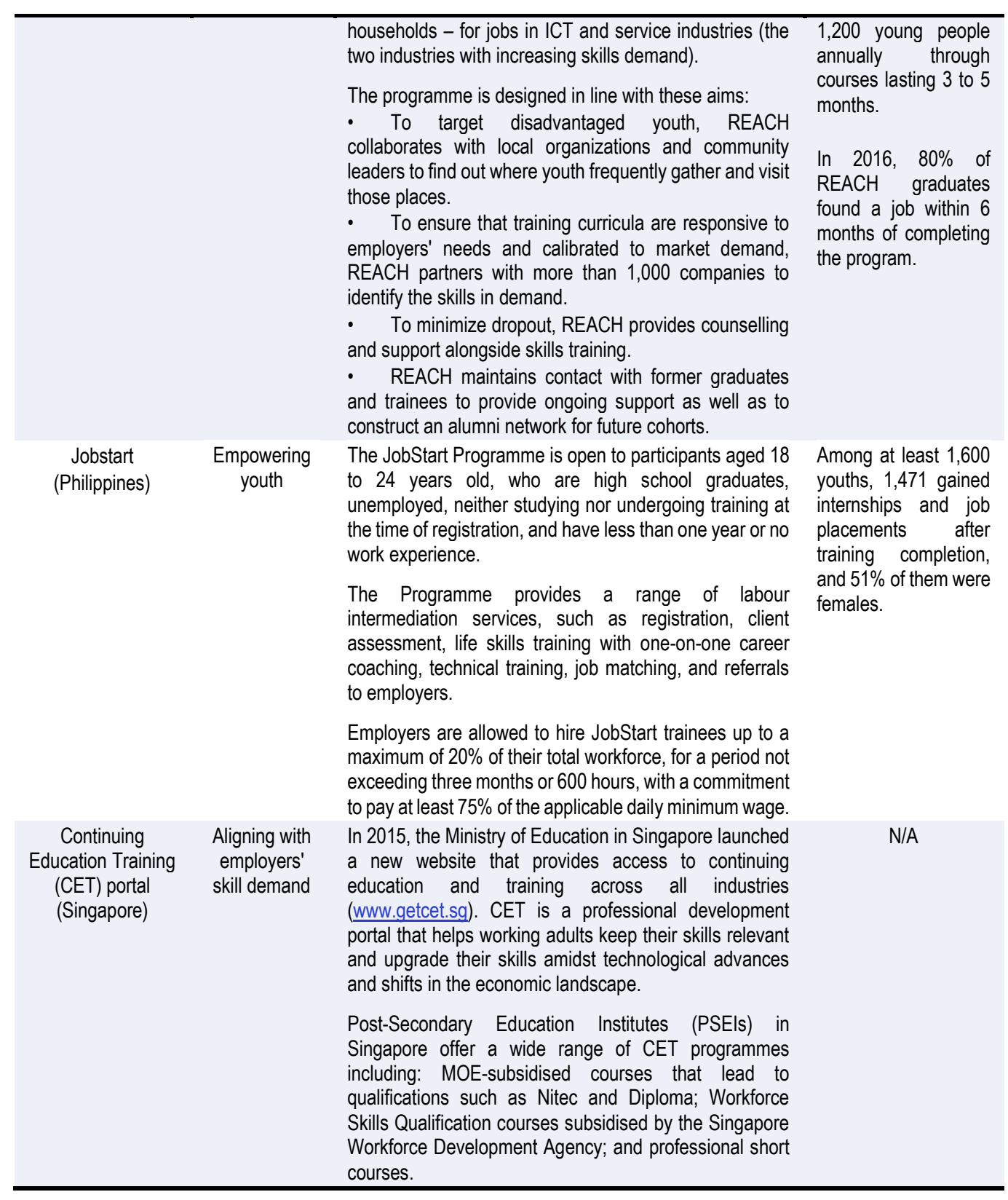

Source: GREAT Women project (ADB, 2013a; UNESCAP, 2013); STVET (ADB (2016); ADB (2013b)); REACH (UNESCO-UNEVOC, 2017); Jobstart programme (OECD/ADB, 2017); CET (UNESCO, 2016b). 


\section{Conclusion and recommendations for further research and analysis}

This paper has identified the main developmental challenges that have resulted in growing wealth disparities within countries in the ASEAN region and has reviewed evidence from international experience to show how TVET systems can be strengthened to increase TVET's effectiveness in addressing these challenges and fostering inclusive growth at the local level. The paper has also provided brief context of the TVET situation in the region and presented good practice examples from across the region to illustrate how some ASEAN countries have used TVET to improve economic and social outcomes.

However, the paper provides only a broad and general overview of the context and usefulness of TVET in the region, so further research and analysis are required to deepen and extend its findings. Suggested areas for future research and analysis include:

- Analysis of the potential costs and benefits of proposed solutions to challenges in the TVET sector - for example, the potential negative and positive implications of new technology on skills and jobs in the future

- Collection of further good practice examples showing how countries, regions and cities have used TVET to improve local economic and social outcomes

- Exploration of the potential for, as well as challenges inherent in, adapting and transferring good practices across countries in the region, especially from the wealthiest to the poorest CLMV (Cambodia, Lao PDR, Myanmar and Vietnam, or CLMV) countries

- Further analysis of TVET institutional arrangements within the ASEAN region to identify system design and funding policy principles to improve the quality and access of local programmes

- A mapping of donor activities in the TVET sector, across and within countries in the region to understand the role of the NGO sector in expanding TVET quality 


\section{References}

Adams, A.V. (2007), The Role of Youth Skills Development in the Transition to Work: A Global Review (Washington DC: World Bank).

ADB (2016), Cambodia: Strengthening Technical and Vocational Education and Training Project (Manila: ADB), https://www.adb.org/sites/default/files/project-document/186038/40555-012-pcr.pdf (accessed on 13 March 2018)

ADB (2014a), Inequality in Asia and the Pacific: trends, drivers and policy implications (Manila: ADB)., https://www.adb.org/sites/default/files/publication/41630/inequality-asia-and-pacific.pdf (accessed 02 March 2018).

ADB (2014b), Technical and Vocational Education and Training in the Socialist Republic of Viet Nam: An Assessment | Asian Development Bank, Asian Development Bank, https://www.adb.org/publications/technical-and-vocational-education-and-training-socialist-republicviet-nam-assessment (accessed on 02 March 2018).

ADB (2013a), Gender equality in the labor market in the Philippines., https://www.adb.org/publications/gender-equality-labor-market-philippines (accessed on 01 March 2018).

ADB (2013b), Gender equality in the labor market in Cambodia., https://www.adb.org/publications/gender-equality-labor-market-cambodia (accessed on 01 March 2018).

Alet, E. and Bonnal, L. (2011), 'Vocational schooling and educational success: comparing apprenticeship to full-time vocational high-school', unpublished paper - available at http://www.tsefr.eu/sites/default/files/medias/stories/SEMIN_10_11/BROWN_BAG/alet.pdf (accessed 21 November 2017).

Almeida, R., Anazawa, L., Menezes Filho, N. and Vasconcellos, L. (2015), 'Investing in Technical and Vocational Education and Training: Does it Yield Large Economic Returns in Brazil?', World Bank Policy Research Working Paper, no. 7246 (Washington DC: World Bank).

ASEAN Secretariat (2016), Projected Gender Impact of the ASEAN Economic Community (Jakarta: ASEAN Secretariat), http://www.asean.org/storage/2015/11/Final-Gender-Dimensions-of-theASEAN-Economic-Community-updated-on-13.03.pdf (accessed 13 March 2018).

ASEAN Secretariat (2015), Table 4.3 Weighted average rate of economic growth, Statistical Year Book 2015, Association of Southeast Asian Nations, Jakarta http://asean.org/storage/2012/05/ASEANStatistic-Yearbook-2015_r.pdf

Atchoarena, D. and Grootings, P. (2009), 'Overview: Changing National VET Systems Through Reforms', in Maclean, R. and Wilson, D. (eds) International handbook of education for the changing world of work: bridging academic and vocational education, Volume II (New York: Springer). 
Barr, J. and A. Attrey (2017), "Building local responsiveness in employment and skills systems in Southeast Asia: Lessons from Malaysia, the Philippines, Thailand and Vietnam", OECD Employment Policy Papers, No. 12, OECD Publishing, Paris, http://dx.doi.org/10.1787/8455fede-en.

Bennell, P. (1996), 'Using and abusing rates of return: a critique of the World Bank's 1995 Education Sector Paper', International Journal of Educational Development, vol. 16, no. 3, pp. 235-248.

Biavaschi, C., Eichhorst, W., Giulietti, C., Kendzia, M., Muravyev, A., Pieters, J., Rodríguez-Planas, N., Schmidl, R., and Zimmermann, K.F. (2012), 'Youth Unemployment and Vocational Training', IZA Discussion Paper, no. 6890 (Bonn: Institute for the Study of Labor).

Bishop, J. H. and Mane, F. (2004), 'The impacts of career-technical education on high school labor market success', Economics of Education Review, vol. 23, no. 4, pp. 381-402.

BMFSF (2009), Pay Inequality between Women and Men in Germany (Berlin: Federal Ministry for Family Affairs, Senior Citizens, Women and Youth).

Bonnal, L., Mendes, S. and Sofer, C. (2002), 'School-to-work transition: Apprenticeship versus vocational school in France', International Journal of Manpower, vol. 23, no. 5, pp. 426-442.

Brunello, G. and L. Rocco (2015), "The effects of vocational education on adult skills and wages: What can we learn from PIAAC?”, OECD Social, Employment and Migration Working Papers, No. 168, OECD Publishing, Paris, http://dx.doi.org/10.1787/5jrxfmjvw9bt-en.

Bucarey Castro, A. (2013), 'The economic return to vocational high schools in Chile', unpublished thesis, University of Chile.

Card, D. (1999), 'The causal effect of education on earnings', in Ashenfelter, O. and Card, D. (eds.) Handbook of Labour Economics (Amsterdam: Elsevier), pp. 1801-1863.

Carneiro, P., Dearden, L. and Vignoles, A. (2010), 'The economics of vocational education and training', in Peterson, P., Baker, E. and McGaw, B. (eds) International Encyclopedia of Education, $3^{\text {rd }}$ edition (Oxford: Elsevier), pp. 255-261.

Carneiro, P. and Heckman, J.J. (2003), 'Human Capital Policy', IZA Discussion Paper, no.821 (Bonn: Institute for the Study of Labor).

Cedefop (2016), 'Leaving education early: putting vocational education and training centre stage Volume II: evaluating policy impact', Cedefop Research Paper, no. 58 (Luxembourg: Publications Office of the European Union).

Cedefop (2013a), 'On the way to 2020: data for vocational education and training policies - Country statistical overviews', Cedefop Research Paper, no. 31 (Luxembourg: Publications Office of the European Union).

Cedefop (2013b), Benefits of vocational education and training in Europe for people, organisations and countries (Luxembourg: Publications Office of the European Union).

Cedefop (2011a), 'The economic benefits of VET for individuals', Cedefop Research Paper, no. 11 (Luxembourg: Publications Office of the European Union). 
Cedefop (2011b), 'The impact of vocational education and training on company performance', Cedefop Research Paper, no. 19 (Luxembourg: Publications Office of the European Union).

Eichhorst, W., Rodríguez-Planas, N., Schmidl, R., and Zimmermann, K.F. (2012), 'A Roadmap to Vocational Education and Training Systems Around the World', IZA Discussion Paper, no. 7110 (Bonn: Institute for the Study of Labor).

Espinoza, R. and Urzua, S. (2015), The Economic Returns to Higher Education: Funding, coverage and quality in Latin America (Washington DC: World Bank).

European Commission (2013), The effectiveness and costs-benefits of apprenticeships: Results of the quantitative analysis (Brussels: European Commission).

Fares, J. and Puerto, O.S. (2009), 'Towards comprehensive training', Social Protection Discussion Paper, no. 0924 (Washington DC: World Bank).

Glick, P.J., Huang, C. and Mejia, N. (2015), The Private Sector and Youth Skills and Employment Programs in Low- and Middle-Income Countries (Washington DC: World Bank).

Global Partnership for Education (2014), Results for Learning Report 2014/15: Basic Education at Risk (Washington DC: Global Partnership for Education).

Gonzalez-Velosa, C., Rucci, G., Sarzosa, M. A. and Urzua, S. (2015), 'Returns to higher education in Chile and Colombia', IDB Working Paper Series, No. IDB-WP-587 (Washington DC: InterAmerican Development Bank).

Hanushek, E.A., Schwerdt, G., Woessmann, L. and Zhang, L. (2017), 'General Education, Vocational Education and Labor Market Outcomes over the Life-Cycle', Journal of Human Resources, vol. 52, no. 1, pp. 48-87.

Hanushek, E.A., Woessmann, L. and Zhang, L. (2011), 'General Education, Vocational Education and Labor Market Outcomes over the Life-Cycle', IZA Discussion Paper, no. 6083, (Bonn: Institute for the Study of Labor).

Hawley, J.D. (2003), 'Comparing the Payoff to Vocational and Academic Credentials in Thailand over Time', International Journal of Educational Development, vol. 23, no. 6, pp. 607-25.

Hoeckel, K. (2008), Costs and Benefits in Vocational Education and Training (Paris: OECD Publishing).

Hoeckel, K. (2007), Key Evidence on Vocational Education and Training Policy from Previous OECD Work (Paris: OECD Publishing).

ILO (2018): ILOSTAT Database (accessed 3 March 2018).

ILO (2014a), Global Employment Trends 2014: Risk of a jobless recovery? (Geneva: ILO).

ILO (2014b), "Survey of ASEAN employers on skills and competitiveness / Emerging Markets Consulting", http://www.ilo.org/wcmsp5/groups/public/---asia/---ro-bangkok/---srobangkok/documents/publication/wcms 249982.pdf (accessed on 28 February 2018). 
ILO (2011), Upgrading informal apprenticeship: A resource guide for Africa (Geneva: ILO).

ILO (n.d.), "Decent work", http://www.ilo.org/global/topics/decent-work/lang--en/index.htm (accessed 14 March 2018).

ILO and ADB (2014), ASEAN Community 2015: Managing integration for better jobs and shared prosperity, (Geneva: ILO and ADB), http://www.ilo.org/asia/publications/WCMS 300672/lang-en/index.htm (accessed on 01 March 2018).

IMF (2016), 'Sharing the Growth Dividend: Analysis of Inequality in Asia', IMF Working Paper, no. WP/16/48.

Jimenez, E.Y., Kiso, N. and Ridao-Cano, C. (2007), 'Never Too Late to Learn? Investing in Educational Second Chances for Youth', Journal of International Cooperation in Education, vol. 10, no.1, pp. 89100.

Kahyarara, G. and Teal, F. (2008), 'The Returns to Vocational Training and Academic Education: Evidence from Tanzania', World Development, vol. 36, no. 11, pp. 2223-42.

Kanbur R. and J. Zhuang (2013), "Urbanization and Inequality in Asia", Asian Development Review, March 2013, Vol. 30/1, pp. 131-147.

Kim, B.M. (2013), 'Estimating Returns to Vocational Education at High Schools in Korea', unpublished manuscript, Department of Economics, University of Southern California - - available at https://dornsife.usc.edu/assets/sites/474/docs/BoMKim 2013 vh.pdf (accessed 21 Nov 2017).

Kingombe, C. (2012), 'Lessons for Developing Countries from Experience with Technical and Vocational Education and Training', International Growth Centre Working Paper, no. 11/1017 (London: IGC).

Kluve, J., Puerto, S., Robalino, D., Romero, J.M., Rother, F., Stöterau, J., Weidenkaff, F. and Witte, M. (2017), Interventions to improve the labour market outcomes of youth:A systematic review of training, entrepreneurship promotion, employment services and subsidized employment interventions (London: International Initiative for Impact Evaluation).

Kluve, J. (2016), 'A review of the effectiveness of Active Labour Market Programmes with a focus on Latin America and the Caribbean', International Labour Office Research Department Working Paper, no. 9 (Geneva: ILO).

Maclean, R. and Pavlova, M. (2013), 'Vocationalization of secondary and higher education: pathways to the world of work', in UNESCO-UNEVOC (ed) Revisiting global trends in TVET: Reflections on theory and practice (Bonn: UNESCO-UNEVOC).

ManpowerGroup (2016), 2016/17 Talent Shortage Survey (Milwaukee: Manpower Group).

Månsson, A .B. and Färnsveden, U. (2012), 'Gender and Skills Development: A Review - Background paper for the EFA Global Monitoring Report 2012', United Nations Girls' Education Initiative Working Paper, no. 4 (New York: UNGEI). 
Mazza, J. (2016), Labor Intermediation Services in Developing Economies: Adapting Employment Services for a Global Age (London: Palgrave Macmillan).

McKinsey \& Company (2014), 'Understanding ASEAN: Seven things you need to know', https://www.mckinsey.com/industries/public-sector/our-insights/understanding-asean-seven-thingsyou-need-to-know (accessed on 14 March 2018).

Moenjak, T. and Worswick, C. (2003), 'Vocational Education in Thailand: A Study of Choice and Returns', Economics of Education Review, vol. 22, no. 1, pp. 99-107.

National Centre for Vocational Education Research (2001), Australian apprenticeships: Facts, fiction and future (Adelaide: NCVER).

National Centre for Vocational Education Research (2000), Women in VET 2000: At a glance (Brisbane \& Melbourne: NCVER).

National Women's Law Center (NWLC) (2002a), Equal opportunity in vocational and technical education: A promise still owed to the nation's young women (Washington D.C.: National Women's Law Center).

National Women's Law Center (NWLC) (2002b), Title IX and equal opportunity in vocational and technical education: A promise still owed to the nation's young women (Washington D.C.: National Women's Law Center).

Neuman, S. and Ziderman, A. (2003), 'Can Vocational Education Improve the Wages of Minorities and Disadvantaged Groups? The Case of Israel', Economics of Education Review, vol. 22, no. 4, pp. 421432.

Neuman, S. and Ziderman, A. (1999), 'Vocational Education in Israel: Wage Effects of the VocEdOccupation Match', Journal of Human Resources, vol. 34, no. 2, pp. 407-420.

OECD (2018), Inclusive Growth website, http://www.oecd.org/inclusive-growth/ (accessed on 02 March 2018)

OECD/ADB (2017), Employment and Skills Strategies in the Philippines, OECD Reviews on Local Job Creation, OECD Publishing, Paris, http://dx.doi.org/10.1787/9789264273436-en

OECD/ILO (2017), Engaging Employers in Apprenticeship Opportunities: Making It Happen Locally, OECD Publishing, Paris, http://dx.doi.org/10.1787/9789264266681-en.

OECD (2016), Latin American Economic Outlook 2017: Youth, Skills and Entrepreneurship (Paris: OECD Publishing).

OECD (2011), 'How does education affect employment rates?', in Education at a Glance 2011: Highlights (Paris: OECD Publishing).

OECD (2010), Learning for jobs., OECD. (Paris: OECD Publishing).

OECD (2006), Employment Outlook (Paris: OECD Publishing). 
Offerdahl, K., Evangelides, A. and Powers, M. (2014), Overcoming Youth Marginalization: Conference Report and Policy Recommendations (New York: Columbia University Global Policy Initiative and Office of the United Nations Secretary-General's Envoy on Youth).

Palmer, R. (2017), Financing TVET in the East Asia and Pacific Region: current status, challenges and opportunities (Washington, D.C.: World Bank Group). http://documents.worldbank.org/curated/en/494921508752195355/pdf/120597-WP-v2P150980-PUBLIC-KWPF-Financing-TVET-in-EAP-Full-Final.pdf

Paz, F. (2017), 'Equity, Quality and Variety of Higher Education', in Ferreyra, M.M., Avitabile, C., Álvarez, J.B., Paz, F.H. and Urzúa, S. (eds) At a Crossroads: Higher Education in Latin America and the Caribbean. Directions in Development (Washington DC: World Bank).

Petersen, B.L. (2013), Regaining a future: lessons learned from youth education in fragile situations (Copenhagen: Danish Institute for International Studies).

Psacharopoulos, G. and Patrinos, H.A. (2004), 'Returns to investment in education: A further update', Education Economics, Vol. 12, No. 2, pp. 111-134.

Quintini, G. and Manfredi, T. (2009), 'Going Separate Ways? School-to-Work Transitions in the United States and Europe’, OECD Social, Employment and Migration Working Paper, no. 90 (Paris: OECD).

Quintini, G., Martin, J.P. and Martin, S. (2007), 'The Changing Nature of the School-to-Work Transition Process in OECD Countries', IZA Discussion Paper, no. 2582 (Bonn: Institute for the Study of Labor).

Rinne, U. and Eichhorst, W. (2015), 'An Assessment of the Youth Employment Inventory and Implications for Germany's Development Policy’, IZA Research Reports, no. 67 (Bonn: Institute for the Study of Labor).

Ryan, P. (2002), Individual returns to vocational education and training qualifications: Their implications for lifelong learning (Adelaide: NCVER).

Ryan, P. (2001), 'The School-to-Work Transition: A Cross-National Perspective', Journal of Economic Literature, vol. 39, no. 1, pp. 34-92.

Song, T.K. and Tang, J. (2016), Managing Skills Challenges in ASEAN-5: Key Barriers to Economic Growth (Singapore: Singapore Management University and JP Morgan).

Tunali, I. (2003), 'General vs. Vocational Secondary School Choice and Labor Market Outcomes in Turkey, 1988-98', Paper presented at the 10th Annual Conference of the Economic Research Forum.

Ul-Haq, M. and Haq, K. (1998), Human Development Report in South Asia 1998 (Delhi, India: Oxford University Press).

UNESCAP (2013), Empowering Women Economically: Illustrative Case Studies from Asia | United Nations ESCAP, United Nations Economic and Social Commission for Asia and the Pacific, http://www.unescap.org/resources/empowering-women-economically-illustrative-case-studies-asia (accessed on 01 March 2018). 
UNESCO (2016a), Gender Review - Creating Sustainable Futures for all: EFA Global Monitoring Report (Paris: UNESCO).

UNESCO (2016b), Enhancing Relevance in TVET: Review of Progress in the Asia-Pacific since 2012, (Bangkok: UNESCO)

UNESCO (2015), Unleashing the Potential: Transforming Technical and Vocational Education and Training (Paris: UNESCO).

UNESCO (2013), Policy Review of TVET in Lao PDR, UNESCO Bangkok, http://bangkok.unesco.org/content/policy-review-tvet-lao-pdr-unesco-2013 (accessed on 02 March 2018).

UNESCO Institute of Statistics (2018), UIS.Stat database (accessed 13 March 2018).

UNESCO-UNEVOC (2017), UNESCO-UNEVOC Promising Practices, http://www.unevoc.unesco.org/go.php?q=PP_REACH (accessed on 02 March 2018).

UNESCO-UNEVOC (2014), TVETipedia glossary (accessed on 02 March 2018).

UNESCO-UNEVOC (2013), Tackling Youth Employment through TVET: Report of the UNESCOUNEVOC Online Conference (Bonn: UNESCO-UNEVOC).

Urzua, S. (2017), 'The Economic Impact of Higher Education', in Ferreyra, M.M., Avitabile, C., Álvarez, J.B., Paz, F.H. and Urzúa, S. (eds) At a Crossroads: Higher Education in Latin America and the Caribbean. Directions in Development (Washington DC: World Bank).

USAID (2013), State of the field report: examining the evidence in youth education in crisis and conflict (Washington DC: USAID).

Vignoles, A., Galindo-Rueda, F. and Feinstein, L. (2004), 'The Labour Market Impact of Adult Education and Training: A Cohort Analysis', Scottish Journal of Political Economy, vol. 51, pp. 26680.

Watson, L. (2000), Where to next? Graduate outcomes from the Australian higher education and vocational education and training sectors (Adelaide: NCVER).

Winkelmann, R. (1996), 'Employment prospects and skill acquisition of apprenticeship-trained workers in Germany', Industrial and Labour Relations Review, vol. 49, no. 4, pp. 658-672.

World Bank (2018), World Development Indicators database (accessed 3 March 2018).

World Bank (2012), World Development Report 2012: Gender equality and development (Washington DC: World Bank). 